Jacek Puchalski

Katedra Książki i Historii Mediów

Wydział Dziennikarstwa, Informacji i Bibliologii

Uniwersytet Warszawski, Warszawa, Polska

jacek.puchalski@interia.pl

ORCID 0000-0003-2023-6988

http://doi.org/10.33077/zbkh.2018.12.puchalski

\title{
„Książka nie jest rzeczą martwą, lecz kwestią życia" - kultura książki w ZSRR w latach 20-30. XX w. w świetle „Teorji psychosfery z jej metodą bibljologiczną" Antoniego Wincentego Kwiatkowskiego (1890-1970)
}

\author{
Abstract
}

"A book is not an inanimated object, but a question of life" a book culture in the USSR in the $20-30$ s of the $20^{\text {th }}$ century in the light of the "Theory of psychosphere and its bibliological method" by Antoni Wincenty Kwiatkowski (1890-1970)

The article presents fragments of the text by Antoni Wincenty Kwiatkowski (1890-1970) „Theory of psychosphere and its bibliological method" signed with his alias Antoni Starodworski, and being stored in the Hoover Institution Archives, Stanford Unviersity. This is a synthetic monography of a book culture in the USSR in the $20-30$ s of the $20^{\text {th }}$ century. In the author's interpretation, theory and practice of book studies agreed with marxist-lenninism ideology was a system of social engineering serving communist indoctrination, upbringing "a Soviet man" (homo sovieticus), as well as development of the communist society and the USSR.

Key words: Antoni Wincenty Kwiatkowski - Antoni Starodworski - "Theory of psychosphere and its bibliological method" - Hoover Institution Archives, Stanford University - book studies - social engineering - communism - USSR.

Słowa kluczowe: Antoni Wincenty Kwiatkowski - Antoni Starodworski - „Teorja psychosfery z jej metodą bibljologiczną" - Archiwum Intytutu Hoovera przy Uniwersytecie Stanforda bibliologia - inżynieria społeczna - komunizm - ZSRR. 
Artykuł stanowi zmienioną i rozszerzoną wersję tekstu Bibliologia w ZSRS $w$ okresie międzywojennym $w$ interpretacji księdza Antoniego Wincentego Kwiatkowskiego (1890-1970)², w którym przedstawiono postać A.W. Kwiatkowskiego ${ }^{2}$ oraz jego poglądy na system książki w Związku Sowieckim w kontekście prac prowadzonych przez niego przed wojną, m.in. w Instytucie Naukowego Badania Komunizmu w latach 1930-1937³. Trafność wielu spostrzeżeń A.W. Kwiatkowskiego potwierdziła budowa systemu książki i prasy w PRL ${ }^{4}$. Po II wojnie światowej bowiem w Polsce i w innych krajach „bloku wschodniego" przyjęto w tym zakresie rozwiązania wypracowane w ZSRR. Autorzy zajmujący się książką i jej instytucjami w okresie PRL, zwłaszcza w początkach Polski Ludowej, zwykle tylko kwitują ten fakt pisząc o ,wzorach radzieckich", szerzej ich nie charakteryzując. Dlatego uważam, że warto przytoczyć in extenso wybrane fragmenty krótkiego (18 stron A5) tekstu „Teorja psychosfery z jej metodą bibljologiczną" A.W. Kwiatkowskiego, będącego częścią drugiego tomu maszynopisu „Struktura i tajemnice centralnej organizacji bolszewizmu markso-leninowskiego" sygnowanego pseudonimem Antoni Starodworski, przechowywanego w Archiwum Instytutu Hoovera przy Uniwersytecie Stan-

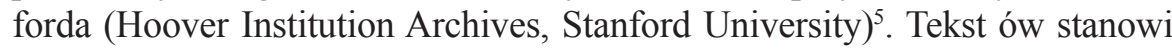
próbę syntetycznego opisu „papierowej rewolucji” jaka dokonała się w Rosji po rewolucji 1917 r. Wbrew uznanej zasadzie transkrypcji nowszych tekstów źródłowych, podaję tutaj wierne cytaty z oryginału „Teorji psychosfery...”, gdyż w mojej opinii sposób pisania charakteryzuje samego autora.

1 W: Szlachta polska i jej dziedzictwo. Księga na 65 lat prof. dr hab. Jana Dzięgielewskiego, [red. D. Kuźmina], Warszawa 2013, s. 259-273. Tam zawarta literatura przedmiotu. Nowsza publikacja na temat A.W. Kwiatkowskiego to: M. Marszal, Komunizm w pogladach Antoniego Kwiatkowskiego (1920-1939), „Studia nad Autorytaryzmem i Totalitaryzmem” 2014, nr 2, s. 87-100.

2 Autobiografia A.W. Kwiatkowskiego przechowywana jest od 1970 r. w Archiwum Hoovera przy Uniwersytecie Stanforda: Hoover Institution Archives, Stanford University, 94305-6010, California [dalej HIA], Collection number: 71013, Antoni Wincenty Kwiatkowski Papers [dalej AWKP], [Box no. 1], A.W. Kwiatkowski, Biografia nie podlegająca publikowaniu. Życiorys Księdza Antoniego Wincentego Kwiatkowskiego = Typewritten biography of A. Kwiatkowski [ukończony 1 maja 1955 r.]. W tym zespole znajduje się też autobiografia $\mathrm{w}$ języku angielskim pt. The Auto-Biography of Priest Antoni Vincenti Kwiatkowski - nieco odmienna od wersji polskiej.

J. Puchalski, Instytut Naukowego Badania Komunizmu w Warszawie (1930-1939). Program, organizacja, zbiory prace ksieggoznawcze, [w:] Bibliologia polityczna. Praca zbiorowa, pod red. D. Kuźminy, Warszawa 2011, s. 214-243. Tam zawarta literatura przedmiotu. Nowsza publikacja na temat INBK to: K. Sacewicz, Komunizm i antykomunizm w II Rzeczypospolitej. Państwo-spoleczeństwo-partie, Olsztyn 2016, s. 28-41.

4 Zob. S.A. Kondek, Papierowa rewolucja. Oficjalny obieg ksiażek w Polsce w latach 19481955, Warszawa 1999 i prace innych autorów na temat dziejów książki i jej instytucji w PRL, m.in. Dariusza Jarosza, Agnieszki Chamery-Nowak czy Agnieszki Łuszpak, żeby wspomnieć tylko badaczy publikujących w ostatnich tomach „Z Badań nad Książką i Księgozbiorami Historycznymi”.

HIA, AWKP, [Box no. 6], Several typewritten manuscripts by A. Starodworski, with annotations by A. Kwiatkowski, A. Starodworski, Struktura i tajemnice centralnej organizacji bolszewizmu markso-leninowskiego, t. 2, k. 195-213. 
Ksiądz A.W. Kwiatkowski zajmował się sowietologią. W zakresie problematyki Rosji Sowieckiej i ruchu komunistycznego był współpracownikiem wywiadu i kontrwywiadu wojskowego (Oddziału II Sztabu Generalnego Wojska Polskiego; od 1928 r. Sztabu Głównego WP), Wydziału Bezpieczeństwa Publicznego Departamentu Politycznego Ministerstwa Spraw Wewnętrznych (MSW), Ministerstwa Spraw Zagranicznych (MSZ) oraz Inspektoratu Głównego Ochrony Skarbowej Ministerstwa Skarbu. Już przed wojną współpracował z założonym w 1933 r. Antykominternem (Ogólnoniemiecki Związek Stowarzyszeń Antykomunistycznych ${ }^{6}$ ) i z innymi zagranicznymi organizacjami i instytucjami antykomunistycznymi. Był również katolicko-konserwatywnym działaczem społeczno-politycznym oraz wydawcą i autorem książek, jak również wielu broszur i artykułów, publikowanych pod swoim nazwiskiem bądź pod pseudonimem A. Starodworski. Przed wojną zgromadził bogatą kolekcję głównie poświęconą ZSRR i ruchowi komunistycznemu, złożoną zarówno ze zbiorów specjalnych (m.in. archiwaliów, ikonografii oraz unikatowych wydawnictw, w tym dokumentów życia społecznego), jak i użytkowych. W 1927 r. założył prywatny Instytut Komunologiczny, który miał zajmować się wszechstronnym badaniem i zwalczaniem komunizmu? Następnie (oficjalnie w 1930 r.) utworzył Instytut Naukowego Badania Komunizmu (INBK). Placówka ta funkcjonowała w praktyce do 1937 r. dzięki wsparciu MSW (Wydziału Bezpieczeństwa Publicznego Departamentu Politycznego - sprawował bezpośredni nadzór nad Instytutem), Ministerstwa Spraw Wojskowych (w praktyce Oddziału II Sztabu Głównego Wojska Polskiego, czyli wywiadu), MSZ i Ministerstwa Sprawiedliwości. Oficjalnie INBK powstał w celach: naukowego badania komunizmu, zaznajamiania społeczeństwa z jego ideologią i przeciwdziałania jego rozwojowi przez poddanie krytycznej analizie. Miał też realizować zadania pozastatutowe na rzecz utrzymujących go resortów, zwłaszcza sporządzając materiały przydatne do operacyjnego rozpracowania m.in. sowieckich sił zbrojnych, Kominternu ${ }^{8}$ oraz Komunistycznej Partii Polski, a także legalnych partii i organizacji tzw. „kryptokomunistycznych” działających w Polsce. A.W. Kwiatkowski, jako rzeczywisty kierownik INBK, chciał też realizować własne ambicje naukowe. Od września 1939 przebywał krótko w Rumunii (był internowany), następnie

Anti-Komintern - Gesamtverband deutscher antikommunistischer Vereinigungen e.V.

AAN, zespół 102/I-III, Instytut Naukowego Badania Komunizmu w Warszawie (Księgozbiór A. Kwiatkowskiego). Opracowania referatowe, korespondencja, odezwy, [A.W. Kwiatkowski], Instytut Komunologiczny, k. 173-174. Zob. też: Memoriat - ulotka na temat Instytutu Komunologicznego opublikowana przez Kwiatkowskiego w Warszawie prawdopodobnie w 1927 r. BN w Warszawie, sygn. III 2.014.605.

8 Międzynarodówka Komunistyczna (Коммунистический интернационал) założona w Moskwie w 1919 r. 
od grudnia 1939 we Włoszech, a od 1943 r. w Niemczech, współpracując m.in. z komitetem „Pro Deo” należącym do Antykominternu. Po wyjeździe z Niemiec w 1945 współpracował z Oddziałem Informacyjnym II Korpusu Polskich Sił Zbrojnych gen. Władysława Andersa we Włoszech ${ }^{9}$. Zmarł na emigracji w Londynie w $1970 \mathrm{r}$.

Przedmiotem zainteresowania A.W. Kwiatkowskiego jako sowietologa były m.in. media w ZSRR. Przed wojną opublikował kilka artykułów poświęconych roli prasy sowieckiej w budowaniu komunizmu w Związku Sowieckim i na świecie. Do ważniejszych należał tekst Psychosfera $w$ Z.S.S.R., ogłoszony w 1931 r. pod pseudonimem A. Starodworski ${ }^{10}$. Rok później pod tym samym pseudonimem wydał opracowanie Radio w Sowietach (Warszawa 1932). Jednak, jak sam stwierdził w autobiografii, jednym z najważniejszych celów jego pracy badawczej była „rekonstrukcja” komunistycznego „systemu bibljograficznego" ${ }^{11}$. Był bowiem przekonany, że wielojęzyczne sowieckie media drukowane nie służyły „wyłącznie potrzebom wewnętrznego życia państwowego" ZSRR, pomagając w przezwyciężeniu izolacji tego kraju

od reszty społeczeństw świata cywilizowanego, by tym sposobem wtargnąć do życia narodów obcych, zburzyć je a na ruinach rozpocząć budowanie ustroju komunistycznego [...]. Polska, lecz i cały świat cywilizowany [...] już się znalazł w sferze poważnego ataku bolszewickiego, prowadzonego przy pomocy książki, prasy ${ }^{12}$.

Wybranym zagadnieniom księgoznawczym, szczególnie antykomunistycznej i komunistycznej produkcji wydawniczej, A.W. Kwiatkowski poświęcił dwie publikacje: broszurę Na froncie intelektualnej ofensywy Bolszewizmu (Warszawa 1932) i rozdział Ksiażkowo-prasowy front bolszewicki w broszurze Katolicyzm a komunizm (A. Starodworski, Warszawa 1936) ${ }^{13}$. Natomiast w rękopisie pozostało główne opracowanie Teorja i system psychosfery bolszewizmu, ukończone w 1937 r. ${ }^{14} \mathrm{~W}$ swojej Biografii z 1955 r. wspominał:

W r. 1927 podczas studjowania literatury bolszewickiej poraz [sic!] pierwszy trafiłem na koncepcję teoretyczną bolszewików stworzenia t.zw. «psychosfery» jako jednego z najpełniejszych narzędzi dla opanowania ogólno-ludzkiej psychyki [sic!] drogą wtłoczenia do umysłów ludzkich zasad doktryny marksizmu-leninizmu ${ }^{15}$.

9 W Ekspozyturze Informacyjnej „W”- Wschód.

10 „Nasza Przyszłość” 1931, t. 13, s. 95-128.

11 A.V. Kwiatkowski, The Auto-Biography..., s. 12.

12 Cyt. za A.W Kwiatkowski, Na froncie intelektualnej ofensywy Bolszewizmu, Warszawa 1932, s. 2, 9-11; Zob. też A. Starodworski, Katolicyzm a komunizm, Warszawa 1936, s. 23-24.

13 A. Starodworski, Katolicyzm..., s. 17-30.

14 A.W. Kwiatkowski, Biografia..., s. 44.

15 Cyt. za tamże, dopisek na s. nlb. 
Podstawowy środek komunistycznej indoktrynacji stanowiło „słowo drukowane"16.

Tej problematyce poświęcony jest właśnie tekst „Teorja psychosfery...”. Tak jak cały maszynopis „Struktury i tajemnic...” został sporządzony w Londynie na przełomie lat 40. i 50. XX w. - najpóźniejsza data jaka się w nim pojawia to 1952 r. ${ }^{17}$ Jednak można postawić hipotezę, że główny zrąb „Teorji...” został opracowany jeszcze przed wojną. Wskazuje na to fakt, iż większość publikacji cytowanych w przypisach przez A.W. Kwiatkowskiego została wydana przed 1935 r. Dobór źródeł przez autora mógł wynikać jeszcze z jednej, zasadniczej przesłanki - otóż, jak zwraca uwagę Krzysztof Migoń, od połowy lat 30. XX w. bibliologia (księgoznawstwo) została ostatecznie uznana w ZSRR za naukę burżuazyjną, znikając jako termin z sowieckiej literatury przedmiotu na kilkanaście lat ${ }^{18}$.

Autor w przypisach do analizowanego fragmentu cytuje zatem: akty prawne Rosji Sowieckiej i ZSRR; dokumenty, wydawnictwa Rosyjskiej Komunistycznej Partii bolszewików - RKP(b) ${ }^{19}$, Wszechzwiązkowej Komunistycznej Partii bolszewików - WKP(b $)^{20}$ i Komunistycznej Partii Związku Sowieckiego (KPZS $)^{21}$ oraz innych organizacji, urzędów, instytucji; publikacje bibliograficzne, np. „Kniżnaja Letopis” („Книжная Летопись”22) i „Żurnalnaja Letopis” („Летопись Журнальных Статей”23) - zwraca uwagę, że autor nie powołuje się w swoim opracowaniu na „Летопись Газетных Статей”, ukazujący się od 1936 r. ${ }^{24}$; piśmiennictwo dotyczące książki i bibliotek, m.in. wielokrotnie cytowany rocznik „Państwowej Centralnej Izby Książkowej RSFSR [właściwie RFSRR - Rosyjska Federacyjna Socjalistyczna Republika

16 A. Starodworski, Struktura i tajemnice..., t. 2, k. 195. Doceniał też znaczenie propagandy radiowej, filmowej, teatralnej, plastycznej i muzycznej, zob. A.W. Kwiatkowski, Biografia..., s. 7; A.V. Kwiatkowski, The Auto-Biography..., s. 10.

17 A. Starodworski, Struktura i tajemnice..., t. 2, k. 202.

18 K. Migoń, Z problematyki teorii księgoznawstwa $w$ ZSRR, „Acta Universitatis Wratislaviensis” nr 72 „Bibliotekoznawstwo” 1968, t. 5, s. 7-8. W PRL istnienie bibliologii jako nauki zanegował Władysław Bieńkowski, zob. tegoż O pseudo-nauce bibliologii i o najpilniejszych zadaniach bibliografii, Warszawa 1953.

19 Nazwa partii komunistycznej w latach 1918-1925.

20 Nazwa partii w latach 1925-1952.

21 Nazwa partii po $1952 \mathrm{r}$.

22 Wydawana od 1906 w Piotrogrodzie, od 1920 r. w Moskwie, zob. К.И. Шафрановский, Работа Книжной палатье в Петрограде, [online] https://100bookchamber.blogspot. com/2016/11/K-I-Shafranovskij-Rabota-Knizhnoj-Palaty-v-Petrograde.html [dostęp 15.08.2018].

23 Ukazujący się od 1926 r., zob. П.А. Чувиков, «Летописи» Всесоюзной книжной палаты, органы государственной библиографии, периодические указатели, профилированные по видам изданий, выпускаемых в СССР, [online] https://www.booksite.ru/fulltext/1/001/008/069/941.htm [dostęp 15.08.2018].

24 Tamże. 
Radziecka]”25, głównie tomy z lat 1927-1928, „Krasnyj Bibliotekar” („Kpacный Библиотекарь”26), „Kniżnyj Front” („Книжный Фронт”27), „Książka i Rewolucja Proletariacka” („Кни́га и Пролета́рская Револю́ция”28).

Na końcu drugiego tomu „Struktury i tajemnic...” został natomiast zamieszczony zestaw literatury m.in. na temat: ,psychosfery”29 - siedem publikacji sowieckich z lat 1926-1935, w tym przepisy dotyczące drukarstwa ${ }^{30}$ i prawa autorskiego ${ }^{31}$; , problemu książki” - osiem pozycji z lat 1928-193932, m.in. encyklopedycznych ${ }^{33}$, bibliograficznych (trzy tomy rzadkiej retrospektywnej bibliografii bibliologicznej i prasoznawczej Augusty Mézieres ${ }^{34}$ zdobyte przez

25 Założona w 1917, od 1920 funkcjonowała jako Rosyjska Centrala Książkowa Pałata w Moskwie (Российская центральная книжная палата), od 1936 r. pod nazwą Wszechzwiązkowej Izby Książki (Всесоюзная книжная палата). Zob. Книговедение. Энииклопедический словарь, гл. ред. Н.М. Сикорский, Москва 1981, s. 120.

26 „Журнал Библиотечной Теории и Практики” - czasopismo publikowane w latach 19231941, zob. Книговедение. Энииклопедический словарь..., s. 66.

27 „Ежемесячный Журнал Книготоргового Обединения Издательств” - czasopismo ukazywało się w latach 1932-1935, zob. О.В. Андреева, История книжного дела в документальных источниках и материалах периодической печати, [online] http://www.hi-edu.ru/e-books/xbook984/01/part-003.htm [dostęp 15.08.2018].

28 Miesięcznik z lat 1932-1940 poświęcony marksistowsko-leninowskiej krytyce bibliografii, wcześniej (1929-1930) wydawany pod nazwą „Книга и Революция”, zob. «Книга и Пролетарская Революичя», [online] https://iterary_encyclopedia.academic.ru/6275/\%C2\%A B $\% \mathrm{D} 0 \% 9 \mathrm{~A} \% \mathrm{D} 0 \% 9 \mathrm{D} \% \mathrm{D} 0 \% 98 \% \mathrm{D} 0 \% 93 \% \mathrm{D} 0 \% 90 \% \mathrm{D} 0 \% 98+\% \mathrm{D} 0 \% 9 \mathrm{~F} \% \mathrm{D} 0 \% \mathrm{~A} 0 \% \mathrm{D} 0 \% 9 \mathrm{E} \% \mathrm{D}$ 0\%9B\%D0\%95\%D0\%A2\%D0\%90\%D0\%A0\%D0\%A1 [dostęp 16.08.2018].

$29 \quad \mathrm{Na}$ kartach nieliczbowanych.

$30 \mathrm{~Np} .$, J. G. Fogelewicz. Dyrektywy podstawowe i prawodawstwo dotyczące druku. OGIZ. Moskwa 1935", cyt. za A. Starodworski, Struktura i tajemnice... - chodzi o Л.Г. Фогелевич, Основные директивы и законодательство о печати, издание пятое, Москва: ОГИЗ, 1935.

31 Np. „S. Kuszkin. Prawo autorskie. Moskwa 1926”, cyt. za A. Starodworski, Struktura i tajemnice... - rosyjskie źródła internetowe (bibliografie i katalogi) nie wykazują takiej pozycji. Być może A.W. Kwiatkowski pomylił się w cytowaniu i chodziło mu o inną pozycję, a mianowicie: Я.А. Канторович, Авторское право, Москва 1926.

32 A. Starodworski, Struktura i tajemnice..., t. 2, k. 311-312.

33 Cytował tomy z pierwszych wydań Małej encyklopedii sowieckiej (Малая советская энциилопедия), Moskwa 1928-1931 oraz Wielkiej encyklopedii sowieckiej (Большая советская энциклопедия), Moskwa 1926-1947.

34 „A.W. Mezjer. Bibljologiczny wykaz słownikowy. Państwowe Wydawnictwo Socjalno-Ekonomiczne. Moskwa. 1934. TT. I-III", cyt. za A. Starodworski, Struktura i tajemnice..., t. 2, k. 312. Chodzi о А.В. Мезьер, Словарный указатель по книговедению. Т. 2-4, Москва-Ленинград 1931-1934. Trzy tomy tej publikacji (pierwszy w 1924) ukazały się, jak podkreśla K. Migoń, „w okresie ideologicznej ofensywy w naukach społecznych i narastającego terroru”. Marksistowscy krytycy pracy A. Mézieres, stwierdzili m.in., że ma ona „swoje korzenie w burżuazyjnej szkole księgoznawstwa”. W efekcie ostatni, czwarty tom dzieła (z 1934) został „,zaaresztowany" w 1935 r. i na pewien czas wycofany z rozpowszechniania. Bibliografia stanowiła zatem rzadkość, nawet w ZSRR. Zob. K. Migoń, Bibliografia pod presja ideologii. Augusta Mézieres i jej «Stowarnyj ukazatiel po knigowiedieniju», [w:] W kręgu książki, biblioteki i informacji naukowej. Księga jubileuszowa dedykowana Profesorowi Zbigniewowi Żmigrodzkiemu, pod red. K. Heskiej-Kwaśniewicz, przy współpracy D. Pietruch-Reizes, Katowice 2004, s. 199-200, 202-203. 
A.W Kwiatkowskiego w czasie pobytu w Niemczech w latach 1943-1945 $5^{35}$ ) i na temat cenzury w ZSRR ${ }^{36}$; , problemu perjodyku" ${ }^{\text {"37 }}$ - dziewięć wydawnictw z lat 1919-193438 i jedna z 1940 r.; ,problemu bibljotecznego" 39 - dwie pozycje z lat 1934-1939 (spis bibliotek z 1934 i podręcznik techniki bibliotecznej w „masowych bibljotekach” z 1939 r.) oraz artykuł z „Propagandysty” („Пропагандист” " ${ }^{40}$ z lutego 1946 r. o bibliotekach ,gabinetów partyjnych”41; „problemu czytelnictwa" ${ }^{42}$ - dwie publikacje z lat 20. XX w. na temat badań czytelnictwa ${ }^{43}$. Wśród źródeł cytowanych $\mathrm{w}$ przypisach i w zestawie literatury oprócz A. Mézieres brakuje opracowań znanych księgoznawców ${ }^{44}$, ale jak podkreśla znawca problematyki K. Migoń na ten temat „wypowiadało się w ZSRR w latach dwudziestych i trzydziestych setki autorów"45.

\section{„Teorja psychosfery z jej metodą bibljologiczną”}

Na wstępie swojego opracowania A.W. Kwiatkowski zwrócił uwagę na funkcjonalne podejście do książki w ZSRR ${ }^{46}$. Powołując się na „Rocznik

35 A.W. Kwiatkowski wspominał, że „w olbrzymich składach mieszczących tysiące skrzyń zwiezionej przez Niemców literatury bolszewickiej i wszelkich rzeczy archiwalnych" odkrył „przede wszystkim 3 tomy rzadkiej encyklopedii bolszewickiej bibliologii (wiedzy o książce)”, cyt. za: A.W. Kwiatkowski: Biografia ..., s. 24; tenże: The Auto-Biography..., s. 33.

36 Niezidentyfikowane „Tajne. Wskazówki dla cenzorów książek” z 1939 r., cyt. za A. Starodworski, Struktura i tajemnice..., t. 2, k. 312.

37 Tamże, k. 312-313.

38 M.in. „B. Gal. Zadania prasy bolszewickiej. Moskwa 1934”, cyt. za tamże, k. 312. Chodzi prawdopodobnie o publikację: Б.М. Таль, О задачах большевистской печати, Москва 1936 źródła internetowe nie wykazują wydania z $1934 \mathrm{r}$.

39 A. Starodworski, Struktura i tajemnice..., t. 2, k. 313.

40 Moskiewskie czasopismo ukazujące się w latach 1926-1946, zob. Пропагандист, [online] https://dic.academic.ru/dic.nsf/bse $/ 124334 / \% \mathrm{D} 0 \% 9 \mathrm{~F} \% \mathrm{D} 1 \% 80 \% \mathrm{D} 0 \% \mathrm{BE} \% \mathrm{D} 0 \% \mathrm{~B}-$ F\%D0\%B0\%D0\%B3\%D0\%B0\%D0\%BD\%D0\%B4\% [dostęp 16.08.2018].

${ }^{41}$ A. Starodworski, Struktura i tajemnice..., t. 2, k. 313.

42 Tamże.

43 „N. Fridjewa i D. Balika. Badanie czytelnika (doświadczenie metodyki). Moskwa 1927”, cyt. za tamże - chodzi о Н. Фридьева, Д. Балика, Изучение читателя (опьт методики), под ред. М.А. Смушковой, Москва-Ленинград 1927; „J.I. Chlebniewicz. Ваdanie interesów czytelnika (Czytelnik masowy). Moskwa 1927”, cyt. za tamże - chodzi prawdopodobnie о Е.И. Хлебцевич, Изучение читательских интересов широких масс (из опытта библиотечной работы в Красной Армии), Москва 1923 - wydanie z 1927 r. nie jest notowane w źródłach internetowych.

44 Przegląd najważniejszych prac dali Stefan Vrtel-Wierczyński, Teoria bibliografii w zarysie, Wrocław 1951, s. 95-124 i K. Migoń, Z dziejów nauki o ksiażce, Wrocław 1979, s. 89-123; tenże, Nauka o książce. Zarys problematyki, Wrocław 1984, s. 60-67.

45 K. Migoń, $Z$ dziejów..., s. 103.

46 W Polsce koncepcję księgoznawstwa funkcjonalnego rozwinął w latach 70. XX w. Karol Głombiowski, zob. O funkcjonalna koncepcję nauki o książe, „Studia o Książce” 1970, t. 1, s. 5-24; tenże, Książa w komunikacji społecznej, Wrocław 1980. 


\section{Państwowej Centralnej Izby Książkowej RSFSR. Książka w r. 1926” („Кни́ж- ная Ле́топись”) pisał bowiem, że:}

Badając zagadnienie «słowa drukowanego» w postaci książki i perjodyku albo gazety, bolszewicy za punkt wyjściowy obrali sobie teorje niemieckiego gazetologa Marcina Moora (1850) [ $\left.{ }^{47}\right]$, który n[a] podstawie analizy pojęcia «gazety» przyszedł do wniosku że istnieje atmosfera psychiczna czyli «psychosfera» [..., która jest] współdziłłaniem ludzi cywilizowanych w ogólnej akcji kulturalnej. W tej psychosferze [...] ludzie nawzajem przekazują objawy zainteresowan, wiedzy i poglądów. Elektronem psychosfery, według Moora, jest «słowo» pisane lub ustne, jako czynnik szerzenia nowin, jako podstawa i komentarz znaczenia nowiny, jej różnorodności i siły. W tym wypadku Moor stosuje aforyzm «Na początku było słowo». Podstawą gazety, według niego, służy «słowo». Markso-leniniści zgadzają się z Moorem, że g[a]zeta nie jest [zadrukowanym] arkuszem papieru, lecz jest organomechanizmem łączącym ludzi z sobą. Gazeta pełni funkcję socjalną, wskutek czego «elektronem» jest «łłowo organizowane» albo «organizacja słów» $\mathrm{i}$ tem samem myśli lub idej z nimi związanych. W oparciu o teorje Moora bolszewicy wyprowadzają metodologiczną stronę poruszonego problemu, mianowicie, że gazeta ma być określana jako proces a nie jako rzecz, jako zjawisko w swej dynamice. Teorja Moora o gazecie dla markso-leninistów posiada analogiczne znaczenie i dla książki. W obu wypadkach oni widzą w tej teorji prawdziwe bibljopsychologiczne podejście do książki [48], wskutek czego te teorje wiążą z bibljologją czyli nauką o książce. Na podstawie takiego założenia markso-leniniści formułują tezę, że zadaniem bibljologji ma być określenie funkcjonalnej zależności różnych elementów procesu książkowego oraz dokładne rozgraniczenie sfery rozwoju każdej poszczególnej wiedzy o książce. Takie rozgraniczenie nie może oznaczać decentralizowania procesu książkowego, lecz odwrotnie, łączenie jego części do celu jednego i wspólnego, mianowicie, do silnego powiązania z sobą wszystkich nauk dotyczących książki jako ogniw jednego łańcucha ${ }^{49}$.

Określone w ten sposób główne zadanie bibliologii w ZSRR miał realizować kolektyw ludzi książki, tak, aby urzeczywistnić hasło «książka nie jest rzeczą marstwą [sic!], lecz kwestją życia» ${ }^{50}$. Autor postrzegał bibliologię sowiecką w dwóch ściśle ze sobą powiązanych sferach - teoretycznej i praktycznej, definiując ją następująco:

Bibljologja markso-leninowska jest nauką o słowie drukowanem w postaci książki i prasy, jednocześnie pełniąc rolę narzędzia dla wytwarzania psychosfery bolszewickiej. Podstawą dla jej rozwoju posłużyło upaństwowienie w ZSSR wszelkich środków wytwarzania

47 Autor niezidentyfikowany.

48 Przed wojną w ZSRR prace twórcy teorii bibliopsychologii Nikołaja Rubakina (Николай Александрович Рубакин) wydawano w latach 20. XX w.: Что такое библиологическая психология?, Ленинград 1924; Психология читателя и книги. Краткое введение в библиологическую психологию, Москва 1929.

49 A. Starodworski, Struktura i tajemnice..., t. 2, k. 195.

50 Tamże. 
słowa drukowanego, zostającego na usługach markso-leninowskiej ideologji, polityki, ekonomji i nauki $\left[{ }^{51}\right]$. Dlatego ta bibljologja w swej istocie została oparta na fundamencie djalektycznego i historycznego materjalizmu, które jej nadały odrębny charakter i kierunek. Jako gałęź [sic!] wiedzy bibljologja posiada własną metodologję jest kultywowana przez Państwową Centralną Izbę Ksiżkową [sic!]. Jako narzędzie psychosfery bolszewizmu, bibljologja podlega specjalnemu ustawodawstwu partyjnemu i administracyjnemu, uniemożliwiających jej zboczenie na tory błędne. Takie obwarowanie bibljologji wypływa z jej ścisłego związku z ruchem markso-leninowskiej polityki, ekonomiki i nauki, czyli związku ustalonego teoretycznie i praktycznie. W znaczeniu przedmiotowem bibljologja ma przed sobą skomplikowane zadania. Z jednej strony ma badać konkretną treść druków, a z drugiej - drogą krytycznego i praktycznego badania procesu książkowego, ma poszukiwać nowego materjału dla tworzenia teorji naukowej potrzebnej dla: badania ekonomiki i techniki wytwarzania książki, oświetlania problemu autorskiego, problemu czytelniczego, drukarskiego, wydawniczego, twórczości artystycznej w procesie powstawania książki oraz teorji i praktyki rozpowszechniania słowa drukowanego ${ }^{52}$.

Podkreślając znaczenie uchwał KPZS, gremiów partyjnych w republikach sowieckich i Kominternu oraz konstytucji i prawodawstwa ZSRR, A.W. Kwiatkowski zwracał uwagę, że

Bibljologja nie jest tylko nauką i teorją, lecz również i praktyką czyli akcją rozwijaną przez rozmaite instytucje partyjne, państwowe, zawodowe i inne, których zadaniem jest wcielanie zasad bibljologji w życie, zabezpieczanie jej rozwoju, i kontrolowanie akcji bibljologicznej ${ }^{53}$. Do ,akcji bibljologicznej”, prowadzonej wedle ,instrukcyj partyjnych”, owe instytucje były zobligowane włączyć członków partii, organizacji naukowych, twórczych, zawodowych, spółdzielczych itp. Do nich należały też zadania ,pilnowania czystości «linii generalnej» w wydawnictwach przez wzmocnienie [...] «czujności bolszewickiej» nad bibljografją i krytyka jako jednych z podstawowych elementów bibljologji”. Równocześnie dbano o:

specjalne zabezpieczenia dla bibljologji drogą: tworzenia specjalnych organów dla zapewnienia czystości bibljologji w duchu markso-leninowskim; zwalczania biurokratyzmu w instytucjach bibljologicznych; rozwijania w prasie działu bibljologji partyjnej; czystki elementów szkodzących akcji bibljologicznej; wykorzystania prasy partyjnej skupiającej ruch masowy dla potrzeb bibljologji; regulowania sieci wydawniczej jako czynnika bibljologicznego; ustalania współpracy bibljologicznej między czynnikami partyjnemi i administracyjnemi; ustalania zadań bibljologji w dziedzinie obrony ZSSR ${ }^{54}$.

Według A.W. Kwiatkowskiego na tak zdefiniowaną bibliologię składało się 17 ,elementów”.

\footnotetext{
51 Tamże, k. 195-196.

52 A. Starodworski, Struktura i tajemnice..., t. 2, k. 196.

53 Tamże.

54 Tamże.
} 
1. „Sprawa autorska-literacka” - zespół zagadnień związanych z twórcą dzieła piśmienniczego, jego obowiązkami, prawami i przywilejami, konkretyzacją wydawniczą jego utworów, stosunkami między nim a partią, organizacją literatów, wydawcą i drukarnią, wreszcie z recepcją jego dzieł. Kwiatkowski zauważył, że w ZSRR od 1928 r. $^{55}$ :

autor indywidualny całkowicie znikł [...] gdyż został wtłoczony w ramy organizacji masowej literatów, przekształcającej go na typowego rzemieślnika kolektywnego, którego działalność została obwarowana specjalnemi regulaminami. Organizacja literatów $\left.{ }^{[5]}\right]$ jest całkowicie zależna od partji i w swych szeregach nie toleruje elementów niepożądanych a osobliwie politycznie szkodliwych ${ }^{57}$.

Związki twórcze pośredniczyły między władzą a środowiskiem literackim, przekazując jej decyzje i oczekiwania. Pełniły równocześnie funkcje kontrolne i tzw. krytyki kolektywnej. W zamian ich członkowie mogli liczyć na różnego rodzaju przywileje.

Działalność literacką w latach 20-30. XX w. normował „Kodeks Prawa Autorskiego”, który nie przyznając „,wieczystych praw autorom”: „reguluje wszelkie sprawy związane $\mathrm{z}$ autorstwem do normy honorarium włącznie. $\mathrm{Z}$ pod ogólnych norm tego prawa są wyjęci jedynie asy piśmiennictwa bolszewickiego, lecz forma ich przywilejów stanowi tajemnicę" 58 .

Kodeks karny oraz postanowienia Sądu Najwyższego RFSRR z 1931 r. definiowały natomiast ,przestępstwa literackie”, które:

są kwalifikowane do rzędu szpiegostwa wojennego, politycznego i gospodarczego na rzecz państw obcych, organizacyj kontrrewolucyjnych lub osób prywatnych i dlatego są karane największemi karami. Do karalnych przestępstw literackich należą wystąpienia kontrrewolucyjne, antisowieckie, antikomunistyczne, dekonspirujące tajemnice dochodzeń administracyjnych i sądowych, gwałcenie reguł wytwórczości prasowej, cenzury, wykorzystywanie bezprawne zakładów poligraficznych i szerzenie wydawnictw pornograficznych $^{59}$.

Literatura i publicystyka, jako narzędzia walki klasowej i kulturalnej, upowszechniane m.in. przez „kółka literackie” masowo zakładane przy organizacjach partyjnych i społecznych, miały służyć aktualnej polityce partii

\footnotetext{
55 Data powołania Wszechzwiązkowego Stowarzyszenia Pisarzy Proletariackich (WSPP Всесоюзное объединение Ассоциаций пролетарских писателей).

56 W działalności WSPP naczelną rolę odgrywało Rosyjskie Stowarzyszenie Pisarzy Proletariackich (Росси́йская ассоциа́ция пролета́рских писа́телей) - organizacja masowa, która zgodnie z polityką partii zmierzała do unifikacji literatury sowieckiej. Obie organizacje działały do 1932 r. Dwa lata później powołano Związek Pisarzy ZSRR (Союз писателей CCCP). Zob.m.in. Росси́йская Ассочиа́иия Пролета́рских Писа́телей, [online] https://bigenc.ru/literature/text/3515393 [dostęp 11.03.2018].

57 A. Starodworski, Struktura i tajemnice..., t. 2, k. 197.

58 Tamże.

59 Tamże, k. 198.
} 
i „światowej rewolucji bolszewickiej”. W praktyce partia stawała się współautorem każdego tekstu opublikowanego w ZSRR.

Partia czuwała też nad właściwym doborem, kształceniem i rozwojem twórczości nowych „kadr literackich” w takich placówkach jak założony w 1933 r. Instytut Literacki im. Gorkiego (Литературный институт имени A.M. Горького) i „Wszechzwiązkowy Komunistyczny Instytut Publicystyki" powołany według A.W. Kwiatkowskiego w 1934 r. - być może chodzi tutaj o działający w latach 1931-1938: Всесоюзный Коммунистический институт журналистики имени „Правды” при Центральном Исполнительном Комитете СССР ${ }^{60}$.

2. „Sprawa wydawnicza” - obejmowała według A.W. Kwiatkowskiego całokształt problematyki konkretyzacji wydawniczej tekstów, czyli

procesu ideologicznego i gospodarczego przekształcenia rękopisu w książkę łącznie z kwestjami technicznego jej wykończenia i przybliżenia do czytelnika jako konsumenta towaru. Głównemi podstawami tego procesu są zagadnienia godzenia wydawniczej ekonomiki, polityki, organizacji i techniki - spotykających się z drukarstwem, księgarstwem, papiernictwem, autorstwem, czytelnictwem oraz z dziedzinami badającemi zjawiska życia kulturalnego, przemysłowego i handlowego. Ustalenie wytycznych w procesie wydawniczym pozwala bibljologji przejść do kwestyj praktycznych drogą rozwiązywania poszczególnych zagadnień, mianowicie: umiejętności kalkulowania, taniości wydawnictw, tworzenia ogólnego planu redakcyjno-finansowego. W metodyce planu wydawniczego bibljologja wysuwa kwestje: polityki cen, polityki wydawniczej, metody opracowania planu łącznie z harmonizacją poszczególnych jelementów [sic!]. Końcowemi problemami sprawy wydawniczej są kwestje typizacji wydawnictw [...], katalogów, informatorów oraz jednolitej terminologji wydawniczej ${ }^{61}$.

Ponadto do zadań bibliologii należało m.in. „regulowanie [...] zewnętrznego wyglądu prasy, sposobu wykonywania druku"62.

Kontrolę nad działalnością wydawniczą sprawowała cenzura, to jest utworzony w czerwcu 1922 r. Główny Urząd do Spraw Literatury i Wydawnictw (GŁAWLIT - Главное управление по делам литературы и издательств ${ }^{63}$ ). Według A.W. Kwiatkowskiego każde wydawnictwo musiało być opatrzone „wizą" Urzędu, zawierającą szczegółowe informacje m.in. na temat: autora, wydawcy, redaktorów, korektorów, czasu oddania tekstu do składu i druku,

60 Zob. Путеводители по Архивам России. Фонды иеентральных органов государственного управления СССР и подведомственных им учреждений. Учебные заведения, [online] http://guides.rusarchives.ru/browse/guidebook.html?bid=203\&sid=1152247 [dostęp 12.03.2018].

61 A. Starodworski, Struktura i tajemnice..., t. 2, k. 198.

62 Tamże, k. 200-201.

63 Zob. m.in. T. Goban-Klas, Literacki Gułag. Gławlit, czyli najwyższe stadium cenzury, [w:] Piśmiennictwo - systemy kontroli-obiegi alternatywne. T. 1, pod red. J Kosteckiego, A. Brodzkiej, Warszawa 1992, s. 46-59. 
formatu papieru, producenta („,fabryki”) papieru, ilości arkuszy, wysokości nakładu, serii i jej numeru, ceny oprawy i drukarni. GLAWLIT zapewniał ochronę „tajemnic partyjnych i państwowych" - wojskowych, ekonomicznych i politycznych - przed ich „zdradą w druku”. Analogiczne zadania spełniał „Główny Urząd do kontroli widowisk i repertuarów” ${ }^{64}$ - Главное управление по контролю за зрелищами и репертуаром, w latach 19231934 Комитет по контролю за репертуаром при Главном управлении по делам литературы и издательств ${ }^{65}$. W ten sposób ideologiczno-polityczną kontrolą objęto wszelkie publikacje ${ }^{66}$, łącznie z literaturą dziecięcą, płytami gramofonowymi i podobiznami Włodzimierza Lenina ${ }^{67}$.

Dopuszczone do rozpowszechniania dzieła powinny trafić do czytelnika, dlatego podstawowym zadaniem podmiotów uczestniczących $\mathrm{w}$ ich publikacji i obiegu było:

zapewnienie aktywności i skuteczności każdej t.zw. «jednostki bibljograficznej» w postaci książki lub perjodyku. W tej kwestji ustawodawstwo bibljologiczne zapewnia możliwość realizowania powziętych planów w dziedzinach nast.: organizacji i dzaiałalności [sic!] instytucyj wydawniczych, książki masowej, propagandy, literatury dla młodzieży, literatury narodowościowej [ $\left.{ }^{68}\right]$, dzieł specjalnych, podręczników, publikowania materjałów oficjalnych, gospodarczej działalności instytucyj wydawniczych, importu i eksportu wydawnictw, transportu wydawnictw ${ }^{69}$.

Najważniejsze instytucje książki w tym systemie to monopole założone w 1930 r.: „Zjednoczenie państwowych instytucyj wydawniczych - OGIZ ${ }^{70}$ (Объединение государственных книжно-журнальных издательств ОГИЗ ${ }^{71}$ ) oraz „Knigocentr” (Книгоцентр - Центр книгожурнального

\footnotetext{
${ }^{64}$ A. Starodworski, Struktura i tajemnice..., t. 2, k. 199.

65 Постановление СНК РСФСР об утверждении положения о Главном управлении по контолю за зрелищами и репертуаром при Наркомпросе РСФСР, 26 февраля 1934, [online] http://www.opentextnn.ru/censorship/russia/sov/law/snk/1931/?id=1216 [dostęp 23.07.2018].

${ }_{66}$ Według Michała Hellera „od powieści do nalepek na pudełkach zapałek”, cyt. za Maszyna i śrubki. Jak hartowat się człowiek sowiecki, Warszawa 1989, s. 211.

67 A. Starodworski, Struktura i tajemnice..., t. 2, k. 199.

68 „Wydawnictwa narodowościowe”, czyli publikacje w językach etnicznych przeznaczone dla nierosyjskiej ludności Związku Sowieckiego były przedmiotem szczególnego zainteresowania A.W. Kwiatkowskiego, zob. tamże, k. 200, zob. też A. Starodworski: Katolicyzm..., s. 12.

${ }^{69}$ A. Starodworski, Struktura i tajemnice..., t. 2, k. 199.

70 Tamże.

71 OGIZ skupiał m.in. wydawnictwa edukacyjno-pedagogiczne, społeczno-gospodarcze, rolnicze, prawnicze, medyczne, literackie, dziecięce i młodzieżowe, wojskowe, muzyczne, słownikowe i encyklopedyczne, sztuk pięknych, sportowe oraz do 1931 r. polityczne (masowe) i naukowo-techniczne, zob. Книга в СССР в 1930-е годы и в период великой отечественной войны,, [in] История книги. Учебник для вузов, под ред. А.А. Говорова, Т.Г. Куприяновой, Москва 1998, [online] http://www.hi-edu.ru/e-books/HB/21-1.htm [dostęp 12.03.2018].
} 
распространения ${ }^{72}$ ) posiadający „,monopol na sprzedaż wszystkich wydawnictw"73.

3. „Papiernictwo” - stanowiło jeden z zasadniczych elementów systemu książki w ZSRR ponieważ było:

związane z procesem wydawniczym, drukarskim, księgraskim [sic!] i czytelniczym. W tej kwestji bibljologja stawia sobie zadanie zglębiania problemu przemysłu papierniczego jako wyrazu kultury papierniczej. Papiernictwo stanowi samodzielną gałęź [sic!] wiedzy, opartą na własnej metodzie [...]. Analiza problemu papierniczego pod względem organizacyjnym i teoretycznym należy do centralnych zagadnień bibljologji [...]. Rozwiązanie problemu papiernictwa bibljologja wiąże z kwestją dynamiki frontu kulturalnego i jego wzmocnienia ${ }^{74}$.

Tematyce produkcji papieru (historii i współczesności) i jego „użycia” poświęcano wiele publikacji, w tym oczywiście na łamach „Przemysłu Papierniczego” („Бумажная Промышленность”, periodyk ukazywał się od $1922 \mathrm{r}^{75}$ ). Według A.W. Kwiatkowskiego studia teoretyczne w tej dziedzinie i wynikające $\mathrm{z}$ nich rozwiązania praktyczne miały zapewnić właściwe oddziaływanie słowa drukowanego na ,świadomość indywidualną i zbiorową" w celu ,jej zdobycia" dla komunizmu ${ }^{76}$.

4. „Poligrafja” - obejmująca zagadnienia drukarstwa i przemysłu poligraficznego, a zadaniem bibliologii w tym obszarze miało być wedle A.W. Kwiatkowskiego oświetlenie ,różnych kwestyj technicznego wytwarzania książki i jej sztuki oraz traktowania tego problemu na płaszczyźnie naukowo-badawczej”. Dalej autor stwierdził, że: „Dziedzina poligraficzna posiada własną metodykę. Składa się ona z szeregu kwestyj, jak: laboratoryjnych badań w przemyśle poligraficznym, techniki drukarstwa [...] nie tylko w ZSSR ale i zagranicą ${ }^{77}$. Publikacjom na ten temat na łamach „Wytwórczości Poligraficznej” („Полиграфическое Производство”, czasopismo wydawane od $1925 \mathrm{r}^{78}$ ) towarzyszyła „pokaźna literatura” dotycząca m.in. rozwiązywania problemów pojawiających się w produkcji książki ${ }^{79}$.

72 Об утверждении устава Государственного объединения книжно-журнальных издательств РСФСР (ОГИЗ), Положения о Центре книго-журнального распространения (Книгочентр) и типового положения о государственном издательстве, входящем в Объединение „,ОГИЗ”. Постановление СНК РСФСР от 08.10.1930, [online] http://7law.info/ussr/act8u/r988.htm [dostęp 12.03.2018]. Więcej na ten temat zob. m.in. Книга в СССР в 1930-е годbl...

73 A. Starodworski, Struktura i tajemnice..., t. 2, k. 199.

74 Tamże, k. 201.

75 Бумажная промышленность, [online] https://dic.academic.ru/dic.nsf/ bse $/ 71691 / \%$ D0 $\% 91 \%$ D $1 \% 83 \%$ D0\%BC\%D0\%B0\%D0\%B6\%D0\%BD $\%$ D0\%B0\%D1\%8F [dostęp 12.03.2018].

76 A. Starodworski, Struktura i tajemnice..., t. 2, k. 201.

77 Tamże, k. 201-202.

78 „Полиграфия”, [online] http://redkayakniga.ru/knigovedenie/item/f00/s01/e0001592/index.shtml [dostęp 12.03.2018].

79 A. Starodworski, Struktura i tajemnice..., t. 2, k. 202. 


\section{5. „Rejestracja i statystyka druków” - szacując produkcję wydawniczą} z lat 1918-1952 (w granicach ZSRR z 1939 r.) na ponad 1,2 mln ,jednostek bibljograficznych" wydanych w ponad 14 mln egzemplarzy A.W. Kwiatkowski stwierdził, że:

Olbrzymia wytwórczość bibljologicznych instytucyj wydawniczych na terenie ZSSR, niezależnie od kontroli ideologiczno-politycznej jest ściśle rejestrowana przez Państwową Centralną Izbę Książkową w jej specjalnych urzędowych tygodniowych organach bibljograficznych pod nazwą: «Kronika Książki» («KNIŻNAJA LETOPIS») i «Kronika czasopisma» («ŻURNALNAJA LETOPIS») $)^{80}$.

Powołując się na sowieckie akty prawne z lat 20-30. XX w. autor zauważył, że rejestracja publikacji stanowiła kolejny etap ich kontroli:

Żadna instytucja poligraficzna nie może wydać nakładu dla wydawcy, zanim nie wyszle [sic!] za pokwitowaniem prawem ustalonej liczby «egzemplarzy obowiązkowych» do odpowiednich instytucyj, które dane wydawnictwo jeszcze raz kontrolują każde pod kątem swych przepisów. Gdy urząd rejestracyjny stwierdzi że wszystko jest w porządku, wówczas rejestruje wydawnictwo, w razie przeciwnym skierowuje sprawę do prokuratury ${ }^{81}$.

6. „Bibljografja” - na wstępie tej części „Teorji psychosfery...” A.W. Kwiatkowski skonstatował, iż:

Bibljologja markso-leninowska utrzymuje zasadę, że bez bibljografji nie może się obejść nauka, państwo i masa, ponieważ ona należy do koniecznych zjawisk bytowych jako wyraz ruchu społecznego odzwoerciadlonego [sic!] w książce. Wsktek [sic!] tego bibljografja musi stanowić podstawę egzystencji książki lub druku. Wychodząc z zego [sic!] założenia bibljologja zaleca uprawianie bibljografji nie tylko w wydawnictwach książkowych lecz i w prasie, by tym sposobem wyjaśnić cele i zadania bibljografji [82]. Do podstawowych zadań bibljografji jako nauki, bibljologja zalicza prawidłowe obliczenie wytwórczości danej epoki, jej opisanie, ułatwienie badaczowi w odszukiwaniu potrzebnych materjałów oraz niesienie wiedzy o książce do szerokich mas czytelniczych. Bibljografja jakkolwiek należy do składowych części bibljologji, jednak sama w sobie stanowi samodzielną dziedzinę wiedzy. Jej zadaniem jest wszechstronne i dokładne opisywanie wszystkich istotnych części składowych książki, stwierdzanie ogólnych i poszczególnych danych książki pod względem wewnętrznym i zewnętrznym, jakościowym i ilościowym ${ }^{83}$.

Głównym celem był rozwój sowieckiej bibliografii dziedzinowej, nazywanej przez autora „specjalną”, co wymagało:

80 Tamże.

81 Tamże, k. 204.

82 Przy czym już w 1924 r. XIII zjazd RKP(b) postanowił m.in.: ,wzmocnić kierownictwo partyjne nad pracą krytyczno-bibliograficzną instytucji wydawniczych, czasopism i gazet”, cyt. za A. Bocheński, Stużba bibliograficzna w ZSRR, „Przegląd Biblioteczny” 1953, z. 1, s. 31.

83 A. Starodworski, Struktura i tajemnice..., t. 2, k. 204. 
opracowywania licznych wykazów, katalogów oraz informatorów sporządzanych według odpowiednich zasad i reguł. Tem się tłomaczy istnienie olbrzymiej ilości wydawnictw bibljograficznych w ZSSR, dotyczących nawet wyjątkowo specjalnych problemów. Tak olbrzymie materjały bibljograficzne zmuszają bibljografję do tworzenia własnej metody, wykazującej tendencje w kierunku nie tylko ustalania zasad i reguł, lecz możliwie największej popularyzacji wiedzy bibljograficznej w postaci różnych podręczników oświetlających teorję i technikę bibljografji ${ }^{84}$.

Jak dalej pisze A.W. Kwiatkowski ,zasadniczym regulatorem” działalności bibliograficznej była Państwowa Centralna Izba Książkowa z jej wydawnictwami rejestrującymi produkcję wydawniczą - od 1926 w 29, od 1931 w 27 , a od 1933 r. w 18 działach głównych ,zbliżonych do projektowanej markso-leninowskiej klasyfikacji wiedzy"85.

Zbudowany w tej formie schemat bibljografji stanowi przejrzystą całość układu życia, stosunków i rzeczywistości panującej w ZSSR. Podając olbrzymie wykazy wydawnictw namacalnie wskazuje na istnienie potężnego frontu bibljograficzno-jednostkowego, stanowiącego podwaliny i siłę markso-leninowskiego systemu psychosferycznego [...]. Bez znajomości bibljografji markso-leninowskiej w całości, nie jest możliwem poznanie istoty i charakteru oblicza duchowego bolszewizmu ${ }^{86}$.

7. „Księgarstwo" - w systemie sowieckiej książki każde wydawnictwo powinno dotrzeć „do rąk czytelnika”. Z tego względu:

bibljologja ustala szereg zarządzeń gwarantujących prawidłowe funkcjonowanie aparatu księgarskiego. Ma on się składać z odpowiedniej sieci składnic wydawnictw oraz ma stosować odpowiednie metody propagowania i podziału wydawnictw.

Praktyczną realizację tych zarządzeń miał zapewnić wspomniany wyżej „Knigocentr", instytucja:

całkowicie [...] uzależniona od WKP(b), wysuwającą postulat realizowania przez organy księgarskie żywego związku z podstawowemi grupami konsumentów książki na podstawie

\section{Tamże.}

85 Zmiany wynikały z krytyki działalności bibliograficznej na początku lat 30. XX w., w opinii partii nie dość dobrze spełniającej podstawowe założenie, że ,wszelka bibliografia, powinna mieć za zadanie bezpośrednie wsparcie budowy socjalizmu, i temu zadaniu podporządkować zarówno dobór, jak i układ materiału”, cyt. za K. Migoń, Bibliografia pod presją ideologii..., s. 199. Wyrazem tego niezadowolenia była uchwała O pracy wydawniczej z 15 VIII 1931 r. KC WKP(b) głosząca, że: «walka o ideologiczną jakość produkcji, o jej zgodność z wymaganiami rozwiniętej ofensywy socjalistycznej i ze współczesnym poziomem myśli naukowej powinna się stać ośrodkiem uwagi akcji wydawniczej. [...] Pod tym względem na równi ze ścisłym doborem kadr redakcyjnych i autorskich ogromnego znaczenia nabiera recenzowanie i bibliografowanie produkcji wydawniczej. Prasa centralna dotąd jeszcze nie postawiła należycie tego najważniejszego zadania, nie wypracowała takiego systemu bibliografowania, który by zabezpieczył autorytatywne i terminowe zaznajamianie szerokich kręgów czytelniczych z piśmiennictwem zarówno społeczno-ekonomicznym i artystycznym, jak zwłaszcza technicznym, co praktycznie dopomogłoby instytucjom wydawniczym w zakresie ulepszenia produkcji», cyt. za A. Bocheński, Stużba bibliograficzna..., s. 31-32.

86 A. Starodworski, Struktura i tajemnice..., t. 2, k. 205. 
studjowania kulturowego i gospodarczego oblicza obsługiwanych rejonów i dzielnic, jak też wymagań czytelników ${ }^{87}$.

Jednak w realiach systemu nakazowo-rozdzielczego w Związku Sowieckim zmagano się ustawicznie z problemem ,zakorkowania książki”. Według A.W. Kwiatkowskiego:

Dla usuwania tego objawu bibljologja mobilizuje wszystkie czynniki księgarskie, bibljotekarskie, kulturalne, społeczne, i gospodarcze istniej[ące] nawet w najdalszych zakątkach kraju. Tak samo w tym celu bibljologja stwarza specjalne wydawnictwa bibljologiczne w postaci trzydniowych i pięciodniowych perjodyków bibliograficznych $\left[{ }^{88}\right]$ posiadających dwa działy. W pierwszym dziale są zamieszczane artykuły poświęcone polityce szerzenia książki, plany działania i piętnowanie instytucyj lub osób «korkuj[ą]cych książki». W drugiej części są podawane wykazy bibljograficzne literatury ${ }^{89}$.

8. „Bibljotekarstwo” - rozumiane jako sieć biblioteczna, obejmująca placówki różnego typu ${ }^{90}$, miało przede wszystkim upowszechniać marksizm-leninizm i wychowywać wiernych, zaangażowanych wyznawców komunizmu ${ }^{91}$ poprzez udostępnianie właściwych wydawnictw:

Bibljologja głosi, że bibljoteka i czytelnik stanowią synonim wyrazów «książka i czytelnik» [ ${ }^{92}$. W oparcie [sic!] o takie założenie bibljologja wysuwa zasadę wszechstronnego poznania problemu propagandy i badania książki bibljotecznej ze względu na wymagania rewolucji markso-leninowskiej, pedagogiki rewolucyjnej nauki i wszelkich specjalności. Celem sprostania takim zadaniom bibljologja utrzymuje zasadę stałego rewidowania stanu bibljotek, by ich całość utrzymać na poziomie aktualności ${ }^{93}$.

W tym kontekście szczególnego znaczenia nabierały kompetencje bibliotekarzy, przeszkolonych ideologicznie i fachowo nie tylko w metodzie pracy i techniki bibliotekarskiej, ale i m.in. w rozwijaniu ,systemu anotacyjnego dla

\footnotetext{
87 Tamże, k. 212.

88 „Пятидневка Книгоцентра”, od 1932 r. „Советская Книготорговля”, zob. Книга в СССР в 1930-е годы...

89 A. Starodworski, Struktura i tajemnice..., t. 2, k. 205.

90 Autor nie scharakteryzował poszczególnych typów bibliotek. Jest to zrozumiałe w świetle obserwacji Ireny Berezowskiej-Morsztynkiewiczowej: „w życiu sowieckim, rozróżnienie pomiędzy biblioteką naukową a biblioteką oświatową przestaje być istotne, gdyż zarówno tu jak i tam, chodzi o jak największy obrót książki, zwiększenie liczby czytelników, udostępnienie każdemu czytelnikowi, każdej książki itd.”, cyt. za Z.S.R.R. Krasnyj bibliotekar, „Bibliotekarz” 1937-1938, nr 2, s. 40.

91 Na ten temat szerzej W. Dobrowolska, Ideologia bibliotekarstwa w Rosji Sowieckiej, Kraków 1934 (odbitka z „Przeglądu Współczesnego” wrzesień 1934 nr 149).

92 Zgodnie z poglądem Lenina, że: „należy upatrywać dumę i sławę biblioteki publicznej nie w liczbie książek rzadkich, ale w ruchu książki wśród ludu, w ilości wciągniętych nowych czytelników, w szybkości dostarczania żądanych książek”, cyt. za I. Berezowska-Morsztynkiewiczowa, Z.S.R.R. Krasnyj bibliotekar..., s. 39-40.
}

93 A. Starodworski, Struktura i tajemnice..., t. 2, k. 206. 


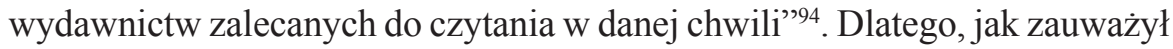
A.W. Kwiatkowski:

Sporo wydano literatury oświetlającej metodę pracy w dużych bibljotekach państwowych, w kwestji konserwowania książki w bibljotece itp. $Z$ temi zagadnieniami bibljologja łączy kwestję potrzeby studjowania interesów czytelników i metody czytania książki. W tym celu jest wydawany organ «Czerwony Bibljotekarz» (Krasnyj Bibliotiekar) $\left.{ }^{95}\right]$, w którym zagadnienia powyższe są oświetlane przez specjalistów drogą uwzględniania problemów bibljopsychologji, psychologji czytelnika, oblicza czytelnika-robotnika, stosunku biedoty do bibljoteki, czytelnictwa masowego itd. ${ }^{96}$

Odnośnie kształtowania kompetencji czytelniczych, zwłaszcza ludności wiejskiej, dzieci i młodzieży oraz kobiet:

Silny nacisk bibljologja kładzie na kwestję metodyki czytania, mającej przynieść korzyść czytelnikowi w przyswajaniu rzeczy czytanych. W tym celu bibljologja wydaje specjalną literaturę oświetlającą kwestje sposobu czytania książki, techniki czytelnictwa, techniki robienia notatek z rzeczy czytanych i sposobu odszukiwania potrzebnych książek ${ }^{97}$.

W innym miejscu opracowania A.W. Kwiatkowski zwracał uwagę na ideologiczno-polityczną kontrolę wszelkich zbiorów (także prywatnych), którą zajmowały się nie tylko służby państwowe (,specjalna CZEKA KSIĄŻKOWA"), ale i m.in. komsomolcy, działacze kultury oraz wszyscy ludzie książki sowieckiej: księgarze, bibliotekarze, kolekcjonerzy, „kniżkorowie” (prasowi korespondenci książkowi) i wreszcie sami czytelnicy ${ }^{98}$. Publikacje uznane za szkodliwe niszczono „ogniem i mieczem"99.

9. „Dziennikarstwo i publicystyka” - jako prasoznawstwo lokowane przez część teoretyków sowieckich w strukturze bibliologii ${ }^{100}$, w opinii

$94 \mathrm{Na}$ ogromną rolę bibliografii zalecającej w ZSRR zwrócił uwagę S. Vrtel-Wierczyński, Teoria..., s. VII. Znaczące z tego punktu widzenia było powołanie w 1937 r. moskiewskiego Instytutu Bibliotekoznawstwa i Bibliografii Zalecającej (Научно-исследовательский Институт Библиотековедения и Рекомендательной Библиографии). Powstał na polecenie Nadieżdy Krupskiej w wyniku reorganizacji Instytutu Bibliotekoznawstwa przy Państwowej Publicznej Bibliotece ZSRR im. W.I. Lenina, zob. Ю.Н. Столяров, Столетие библиотечного образования в СНГ и республиках ближнего зарубежья, [online] http://docplayer.ru/216495-Stoletie-bibliotechnogo-obrazovaniya-v-sng-i-respublikah-blizhnego-zarubezhya.html [dostęp 24.08.2018].

${ }_{95}$ Oczywiście nie tylko „w tym celu”, bowiem jak stwierdziła Wanda Dobrowolska zawartość „Krasnego Bibliotekara” stanowiła odbicie aktualnych prądów w sowieckich republikach, zob. Bibliotekarstwo w Rosji Sowieckiej. Krasnyj Bibliotekar - Żurnat Bibliotecznoj Teorii i Praktiki. - Organ Glawpolitprosweta. Pod redakciej M. A. Smuszkowoj. Gosudarstwennoje izdatelstwo [Moskwa] 1929. God izdanija sedmoj, „Przegląd Biblioteczny” 1931, R. 5, s. 85.

96 A. Starodworski, Struktura i tajemnice..., t. 2, k. 206.

97 Tamże.

98 Tamże, k. 212.

99 Tamże.

100 Np. przez Mikołaja Somowa, zob. Н.М. Сомов, Состав книговедения: библиология библиография - журнализм. К построению системы книговедения, Москва 1931. Zob. też S. Vrtel-Wierczyński, Teoria bibliografii..., s. 117; K. Migoń, Z dziejów..., s. 104; tenże, Biblio- 
A.W. Kwiatkowskiego stanowiły dział traktowany:

z największą ścisłością, ponieważ dotyczy rzeczy nowych i nie posiadających precedensu w dziennikarstwie. Tutaj główną rolę odgrywa publicysta zbiorowy o charakterze klasowym działający na określonych podstawach teoretycznych i technicznych ${ }^{101}$.

W tej dziedzinie zajmowano się zagadnieniami dotyczącymi m.in. „kultury gazety, języka, stylu, [...] etyki reporterskiej, reklamy, czytelnictwa", rozpowszechniania i nakładów prasy, metodyki i techniki pracy korespondentów prasowych. Problematykę tę ujmowano w kontekście roli prasy w „budownictwie bolszewickim” i jej „,wiernej służby na rzecz ideologji markso-leninowskiej”. A.W. Kwiatkowski uważał przy tym, że sowiecki „system prasowy” został stworzony przy wykorzystaniu studiów nad prasą przedrewolucyjną i zagraniczną: amerykańską, angielską, francuską i niemiecką ${ }^{102}$.

Dalej, analizując szczegółowo strukturę oraz indywidualną i kolektywną pracę redakcji prasowych oraz osób współpracujących autor uwypuklił znaczenie ich kontroli wewnętrznej i zewnętrznej - ze strony organizacji partyjnych, zawodowych itp. oraz odpowiednich organów państwowych. Zwrócił także uwagę na specyficzną $\mathrm{w}$ porównaniu z prasą zachodnią rolę korespondentów, stanowiących w jego opinii „trzon dziennikarstwa bolszewickiego":

Dziennikarz [...] w ZSSR [...] może być tylko kolektywnym, [...] jego strona indywidualna odgrywa rolę wyłącznie techniczną i zależną od dyrektyw. Korespondent bolszewicki posiada różne formy, zależnie od sfery, w której pracuje (rabkory [ $\left.{ }^{103}\right]$, sielkory [104], fabkory $\left[{ }^{105}\right]$, wojen kory $\left[{ }^{106}\right][\ldots]$ itd.). [...] Korespondenci s[a] szkoleni w odpowiednich zakładach o różnych poziomach. [...] Od korespondenta [sic!] masowego bibljologja wymaga pracowitości i sumienności, gdyż jego zadaniem jest mobilizow[an]ie masy czytelniczej i zmuszanie jej do reagowania na wiadomości podane w gazecie. [...] Korespondenci nie mają obowiązku należenia do partji, zato [sic!] partja oddziaływuje [sic!] na nich pod względem ideologicznym ${ }^{107}$.

Według A.W. Kwiatkowskiego chroniona prawem działalność korespondentów służyła również aparatowi represji ${ }^{108}$.

grafia pod presją..., s. 195.

101 A. Starodworski, Struktura i tajemnice..., t. 2, k. 206.

102 Tamże.

103 Korespondenci robotniczy.

104 Korespondenci wiejscy.

105 Korespondenci fabryczni.

106 Korespondenci wojskowi.

107 A. Starodworski, Struktura i tajemnice..., t. 2, k. 208

108 Autor artykułu Narodziny kołchozów - „Światowid” 03.09.1933, R. 10, nr 36 (473) informował, że owi korespondenci byli najczęściej formalnymi konfidentami policji politycznej: „«Sielkor» - wiejski korespondent, zwykle konfident G. P. U.”, czyli Państwowego Zarządu Politycznego przy Ludowym Komisariacie Spraw Wewnętrznych RFSRR (Государственное 
Większa część armji takich korespondentów obsługuje t.zw. «gazetę ścienną», wykonaną odręcznie i wywieszoną w każdej instytucji państwowej, zawodowej, przemysłowej, partyjnej itd. Ta gazeta służy ma[t]erjałem podstawowym dla wywiadu i prokuratury dla wykrywania elementów szkodliwych dla ustroju bolszewickiego ${ }^{109}$.

Kolejną formą ich działalności było przesyłanie anonimowych informacji (a właściwie donosów) do prasy. Komunikaty tego rodzaju otaczano:

wyjątkową opieką prawa bibljologicznego. Aby nie traciły na aktualności, prokuratura sowiecka ma stale wglądać do ich treści i nadawać bieg sprawom w nich poruszonym. Stąd powstaje ścisła współpraca korespondentów z sądownictwem sowieckiem [...]. Tem się tłomaczy fakt, że do każdej redakcji rząd sowiecki przydziela prokuratora do przeglądania prasy i wszczynania dochodzeń. Ustawy bibljologiczne surowo zabraniają dekonspirowania nazwisk korespondentów lub ich prześladowania przez osoby urażone ${ }^{110}$.

10. „Kadry bibljologów” - w ZSRR przygotowywano je kształcąc „specjalistów w poszczególnych dziedzinach bibljologicznych" i zaznajamiając z całokształtem problematyki poprzez studia wyższe ${ }^{111}$, szkolenia praktyczne i specjalne kursy ${ }^{112}$ oraz seminaria organizowane m.in. dla bibliotekarzy i księgarzy ${ }^{113}$.

11. „Bibljofilja” - zdaniem A.W. Kwiatkowskiego misją towarzystw miłośników książki było krzewienie jej „,kultury” i zachęcanie do jej ,,propagandy".

Program ich działalności polega na rozwiązywaniu zagadnień kulturalnego kolekcjonowania książki, zachowania wewnętrznej i zewnętrznej kultury książki, jej upiększeń i ilustracyj. Do tego należy propagowanie zamiłowania do grafiki i studjowania ekslibrisów. Spora literatura w tej dziedzinie odtwarza wszelkie dezyderaty i poczynania bibljofilów, dostarczając orjentacji w kwestjach teoretycznych i praktycznych ${ }^{114}$.

Oczywiście, księgozbiory prywatne miały funkcjonować jako element systemu książki. Dlatego poddawano je kontroli i selekcji - usuwano z nich zwłaszcza wydawnictwa przedrewolucyjne i zawierające treści uznane za „niebezpieczne dla światopoglądu marksistowsko-leninowskiego"115.

12. „Historja książki” - dziedzina bibliologii o ,charakterze specjalnym”, która usiłując ,syntetyzować ogólne materjały dotyczące historji książki, [...] dąży do wyróżnienia historji książki rewolucyjnej i sowieckiej”. Na

\footnotetext{
Политическое Управление при НКВД РСФСР, ГПУ НКВД РСФСР).

109 A. Starodworski, Struktura i tajemnice..., t. 2, k. 208.

110 Tamże.

111 Do lat 30. XX w. wiedzę o książce wykładano w wielu szkołach wyższych, instytutach i towarzystwach księgoznawczych, zob. K. Migoń, Z problematyki..., s. 5-8.

112 A. Starodworski, Struktura i tajemnice..., t. 2, k. 208.

113 Tamże, k. 211.

114 Tamże, k. 209.

115 Tamże.
} 
podstawie swoich źródeł A.W. Kwiatkowski stwierdził, że:

Pod względem metodycznym całość tego problemu bibljologja dzieli na pięć zasadniczych części [...]: historja piśmiennistwa [sic!] do okresu neolitycznego [sic!], historja druku książki i perjodyku wogóle [sic!] a w szczególności rosyjskiego, historja książki i prasy bolszewickiej przedrewolucyjnej i porewolucyjnej, ich tradycje i kronikę wydarzeń wydawniczych, historja tajnych drukarń, redakcyj itp., historja księgarstwa nakładowego, bibljotek, grafiki i działaczy na tem polu ${ }^{16}$.

13. „Wydawnictwa zagraniczne” - problematykę współczesnego, zagranicznego uniwersum druku traktowano w ZSRR jako odrębne zagadnienie i według A.W. Kwiatkowskiego „ten dział bibljologji markso-leninowskiej” posiadał olbrzymie znaczenie pod względem ,porównawczym, informacyjnym, politycznym i praktycznym". Starano się mianowicie poznać książkę i prasę zagraniczną, procesy ich wytwarzania, rozpowszechniania i odbioru, także po to, by zapewnić skuteczność akcji szerzenia ideologii komunistycznej za pomocą druku poza granicami Związku Sowieckiego:

W tej dziedzinie bibljologja dąży do stworzenia wyczerpującego systemu na podłożu informacyjnem i praktycznem. Polega ona na tworzeniu systematycznych wykazów bibljografji zagranicznej, zjazdów bibljograficznych, stowarzyszeń, instytucyj i bibljotekarstwa ${ }^{117}$.

14. „Encyklopedje” - zaliczając tę problematykę do działów bibliologii ${ }^{118}$ A.W. Kwiatkowski uważał, że opracowane wedle zasad materializmu dialektycznego i historycznego publikacje tego typu - m.in. „Wielka Encyklopedja Sowiecka”, „Techniczna encyklopedja”, „Literacka encyklopedja” - miały ogromne znaczenie, bowiem stanowiły wyjątkowe narzędzie

do zmiany poglądu na życie w stosunku do społeczeństw zachodnich, dzięki czemu powstaje przepaść światopoglądowa między Zachodem a «narodem sowieckim», powodująca istnienie dwóch sprzecznych z sobą obozów i światów. Przy pomocy działu encyklopedycznego bibljologja markso-leninowska ma możność kierowania mentalnością społeczną, wprzęgając ją do służby na rzecz ideologji markso-leninizmu ${ }^{119}$.

15. „Zjazdy bibljologiczne” - autor stwierdzał, iż rozwój bibliologii „markso-leninizm uzależnia nie tylko od wymagań życiowych lub samych

116 Tamże. A.W. Kwiatkowski powoływał się w przypisie (k. 312) na publikację Cmambu и материаль по истории книги в России, Москва-Ленинград 1936. Труды Института книги, документа и письма, вып. 5.

117 A. Starodworski, Struktura i tajemnice..., t. 2, k. 209.

118 Ma to uzasadnienie, czego przykładem tekst: „Nowosadskij I. W. Encyklopedia jako problem teorii księgoznawstwa" przytaczany w recenzji: A.S., Trudy Instituta Knigi, Dokumenta i Pisma. II. Stat i i po historii enciktopedij. Leningrad 1932. Izd-wo Akad. Nauk. SSR. $8^{\circ}$, str 4 nlb. +72 , „Przegląd Biblioteczny” 1933, R. 7, s. 176. Recenzowana publikacja została wydana przez Instytut Książki, Dokumentu i Pisma funkcjonujący w latach 1918-1936 przy Akademii Nauk w Leningradzie, zob. Институт Книги, Документа и Письма, [online] http://redkayakniga.ru/knigovedenie/item/f00/s00/e0000776/index.shtml [dostęp 25.08.2018].

119 A. Starodworski, Struktura i tajemnice..., t. 2, k. 210. 
wymagań książki, lecz i od tendencyj teoretycznych i praktycznych, znajdujących wyraz w różnych zjazdach organizacyj” związanych z książką i prasą. Spotkania takich gremiów służyły zarazem postępowi w „badaniu książki i związanych z nią zagadnień", podnoszeniu kwalifikacji kadr, ale przede wszystkim informowaniu uczestników o intencjach i decyzjach władzy. Ich tematyka obejmowała wszystkie dziedziny sowieckiego uniwersum druku. Według A.W. Kwiatkowskiego taka forma „bibljologicznej akcji markso-leninowskiej świadczy o tendencji wykrzesywania siły żywej i dynamicznej, potrzebnej [...] dla rozwijania zjawiska i systemu psychosferycznego". Stąd duże znaczenie przypisywał publikacjom pozjazdowym upowszechniającym wiedzę o stanie i kierunkach badań oraz rozwiązaniach praktycznych w poszczególnych dziedzinach bibliologii marksistowsko-leninowskiej ${ }^{120}$.

16. „Informatory” - według A.W. Kwiatkowskiego były to „wszelkie wykazy udzielające informacyj o roli książki co do jej przeszłości [...] jak i jej zadań obecnych". Wydawnictwa tego typu miały ułatwiać przyswajanie książki jako „specjalnego przedmiotu kultury”, rozwój i popularyzację w społeczeństwie radzieckim księgoznawstwa jako dyscypliny naukowej oraz dostarczanie przykładów praktycznych rozwiązań w poszczególnych dziedzinach składających się na bibliologię. Dlatego od ludzi książki wymagano ich bieżącego studiowania ${ }^{121}$.

17. „Czytelnictwo” - zgodnie z leninowskim hasłem „książki do masy przez masę" podstawowym celem sowieckiego systemu książki i prasy było według A.W. Kwiatkowskiego zdobycie „czytelnika masowego i masy posłusznej rządom bolszewickim":

Dlatego WKP(b) wysuwa zasadę dawania czytelnikowi książki aktualnej pod względem politycznym, by koncentrowała masę dookoła zagadnień politycznych i ekonomicznych $\mathrm{i}$ by pełniła rolę drogowskazu w walce z odchyleniami od generalnej linii komp[a]rtji. W tym celu WKP(b) w r. 1931 [uchwałą z 15 sierpnia $O$ pracy wydawniczej] wprowadza zasadę badania profilu czytelnictwa danego terenu ze ścisłem obliczaniem jego potrzeb dla stworzenia żywego związku między książką a czytelnikiem, by tym sposobem wciągnąć najszersze warstwy zorganizowanego społeczeństwa nie tylko do akcji intensywnego szerzenia książki lecz i do pełnienia kontroli tej akcji przez kompartję. Wszystkie wysiłki bibljologji markso-leninowskiej są skoncentrowane dookoła czytelnika, jako głównej osi zagadnienia bibljologicznego ${ }^{122}$.

Zdaniem autora w ZSRR wyróżniano cztery główne kategorie czytelników: 1 - CZYTELNIK MASOWY - mający wchłaniać materjały drukowane, przeznaczone dla realizowania komunistycznych poczynań budownictwa bolszewickiego.

$\begin{array}{ll}120 & \text { Tamże. } \\ 121 & \text { Tamże. } \\ 122 & \text { Tamże. }\end{array}$


2 - CZYTELNIK INDYWIDUALNA [sic!] - czyli element osobowy, wymagający kształcenia indywidualnego w kierunku przyswojenia zasad doktryny markso-leninizmu i politycznych dążeń kompartji. Czytelnika indywidualnego dokładnie studjuje bibljologja pod względem psychicznym, by słowo drukowane docierało do jego świadomości. Z tego względu bibljologja wymaga od instytucyj księgarskich, by z uwagą traktowały czytelnika jako nabywcę ksiżki [sic!] i by swym systemem obsługi czyniły wszystko, by go pozyskać sobie, zwłaszcza w wypadkach braku żądanego materjału.

3 - CZYTELNIK OBCOKRAJOWY - w ZSSR [123] - jest równueż [sic!] zgóry [sic!] zaliczony do kategorji czytelnika zwykłego, lecz bardziej uprzywilejowanego, któremu bibljologja zaleca podsuwać do ręki nie tylko książki techniczne ale i polityczne. Przewidując powstawanie trudności językowych, bibljologja wysuwa zasadę obsługiwania tego czytelnika różnemi rzeczami pomocniczemi i słownikami, bez których on będzie stracony dla książki.

4-CZYTELNIK ZAGRANICZNY - poza granicami ZSSR - również jest objektem troski dla bibljologji markso-leninowskiej. [...] Dla tej kategorji czytelnika bibljologja sporządza wydawnictwa w ZSSR różnemi drogami transportowane do krajów zagranicznych nie tylko jawnie ale i tajnie ${ }^{124}$.

Obsługa wymienionych kategorii czytelników należała według A.W. Kwiatkowskiego do „Centrali Książkowej”. Skuteczność jej działania miała zapewnić z jednej strony należyta ,informacja o książce” zawarta w wydawnictwach branżowych z „Pięciodniówką Centrali Książkowej” („Пятидневка Книгоцентра”, od 1932 r. „Советская Книготорговля”) na czele, z drugiej podmioty współpracujące:

org[a]nizacje społeczne opracowujące plany sieci księgarskiej, kampanij masowych i kontroli działalności; księgarnie - stanowiące podstawowe komórki w akcji propagowania książki; kioski - [...] ustawione w różnych punktach danego terenu; wystawy - jako jeden z łatwych sposobów propagowania książki [...]; bibljoteki - będące szkołami dla mobilizowania i kształcenia masy; spółdzielnie - jako techniczne aparaty propagandy książki ${ }^{125}$. Największa rola w rozwijaniu czytelnictwa książki ,markso-leninowskiej” przypadła księgarzom zobowiązanym do:

stałego studjowania literatury bibljograficznej i czasopism fachowych celem szybkiego orjentowania się w beiżących [sic!] zagadnieniach wewnętrznej i zewnętrznej polityki [...] bolszewizmu światowego oraz w problemach technicznych. Dlatego księgarz ma być wrogiem biurokratyzmu i szkodnictwa. Wskutek tego WKP(b) stale podciąga księgarzy i zmusza ich być dobrymi fachowcami czyli bibljografami, by radzili sobie z systematyzacją i asortymentem materjału i zadośćczynili [sic!] wymaganiom nabywcy. W tym celu pracownicy księgarscy są szkoleni w specjalnych seminariach i kursach oraz premjowani

123 Zapewne chodzi o obcokrajowców czasowo podejmujących pracę w ZSRR.

124 A. Starodworski, Struktura i tajemnice..., k. 211.

125 Tamże, k. 212. 
za wydatną pracę fachową. Niezależnie od tego są systematycznie zwoływane konferencje dla oświetlania sprawy dynamiki szerzenia książki i szturmowej pracy księgarzy ${ }^{126}$.

Do księgarzy, co podkreślił w 1932 r. Józef Stalin, należało też zwalczanie „książki szkodliwej” poprzez kontrolę zawartości powierzonych im „składów literatury" i wycofywanie z nich publikacji niepożądanych ${ }^{127}$.

W opinii A.W. Kwiatkowskiego realizacja hasła „książka do masy przez masę" nie miała charakteru kampanijnego, lecz była bieżącą, kontrolowaną akcją, na którą składały się takie działania jak:

zbieranie «rubla kulturalnego» połączone ze zwalczaniem «bohaterów oddających książki myszom na pożarcie»; masowe kolportarze [sic!] po uprzedniem wyszkoleniu kolporterów; odliczanie 25 kopiejek z poborów robotników i chłopów na rzecz książki; częste zebrania terenowe; szerzenie t.zw. «karty kulturalnej» czyli wykazu zawartości małych bibljoteczek odpowiadających profilowi danego terenu, realizowane przez brygady komsomolskie przenikające do prywatnych mieszkań; «stafety książkowe» startujące według określonej marszruty [...]; kampanje szerzenia książki łączone z określonemi zdaniami politycznemi, [...] gospodarczemi itd.; kursy, obozy, organizacje, punkty transportowe itp.; armja, szkoła i radjo i prasa lokalna z udziałem wyszkolonych [...] «kniżkorów»; publikacje statystyczne oświetlające stan i dynamikę propagandy książki i stanowiące podsumowanie ogólnych wyników tej akcji z wyrażeniem dezyderatów na przyszłość ${ }^{128}$.

Opisana w ten sposób przez A.W. Kwiatkowskiego „,bibljologja markso-leninowska" wypełniała jego zdaniem skutecznie nie tylko ZSRR, ale i świat (,psychosferę" o ,zasięgu światowym”) ideami marksistowsko-leninowskimi, niszcząc przy tym bądź wypierając idee z nimi sprzeczne ${ }^{129}$.

\section{Konkluzje}

- Można powiedzieć za K. Migoniem, że A.W. Kwiatkowski starał się opisać kulturę książki w ZSRR, czyli „ogół zjawisk i procesów, zasobów materialnych i duchowych" z nią związanych ${ }^{130}$. Ściślej zaś - w jego interpretacji źródeł sowieckich jako teoria i praktyka ,,bibljologja markso-leninowska” stanowiła system inżynierii społecznej służący komunistycznej indoktrynacji. Jego działanie miało prowadzić do ukształtowania - „człowieka sowieckiego” (homo sovieticus), budowy społeczeństwa komunistycznego i ZSRR. Narzędziem ,,inżynierów dusz i umysłów”, ,psycho-inżynierów, psycho-konstruk-

126 Tamże.

127 Tamże.

128 Tamże, k. 213.

129 Tamże.

130 K. Migoń, «Kultura książki» - wyrażenie potoczne, kategoria badawcza, czy specjalność naukowa?, [w:] Ludzie i książki. Studia i szkice bibliologiczno-bibliograficzne. Księga pamiątkowa dedykowana Profesor Hannie Tadeusiewicz, [red. W. Andrysiak], Łódź 2011, s. 48. 
torów", według określenia z 1922 r. pisarza futurysty Sergieja Trietiakowa ${ }^{131}$, było słowo drukowane ujęte w idealną książkę (i periodyk) będącą wynikiem współdziałania partii, państwa, autorów, grafików, wydawców, drukarzy, księgarzy, bibliotekarzy, popularyzatorów, propagandystów oraz samego zorganizowanego, aktywnego czytelnika masowego.

- Opis bibliologii jako nauki autorstwa A.W. Kwiatkowskiego odzwierciedla poglądy takich księgoznawców jak Igor Nowosadskij (Игорь Всеволодович Новосадский). W artykule Теория книговедения и марксизм. Критика современного книговедения z 1931 r. ${ }^{132}$ stwierdził on, że przedmiot księgoznawstwa stanowi treść, forma materialna i funkcja społeczna książki, a podstawę jego problematyki badawczej ewolucja procesów książkowych „w zależności od rozwoju stosunków społecznych w procesie walki klasowej”"133. - Widoczny jest brak krytycyzmu A.W. Kwiatkowskiego w stosunku do wykorzystywanych źródeł. Z tekstu „Teorji psychosfery...” wynika, że był przekonany o prawidłowym działaniu systemu, wskazując tylko na problem „korkowania się książki” w ZSRR. A przecież w studiowanych przez niego materiałach, choćby na łamach „Krasnego Bibliotekara”, nie brakowało krytyki (i samokrytyki) różnych niedoskonałości w praktycznej realizacji teoretycznych założeń. Zwracali na to uwagę inni polscy autorzy, na przykład Helena Radlińska, która w publikacji z 1924 r. analizowała sowiecką politykę biblioteczną w kontekście oświatowym, społecznym i politycznym ${ }^{134}$. Kilka lat później na „marny stan” bibliotekarstwa w ZSRR na przełomie lat 20 i 30. XX w. wskazywała Wanda Dobrowolska, konkludując: „Wielkie hasła i teoretyczno-programowy rozmach załamuje się wobec twardej [sowieckiej] rzeczywistości”'135. Inicjatywy podjęte w tym okresie (m.in. przez zjazdy bibliotekarskie) niewiele poprawiły tę sytuację, bowiem:

wiele bibljotek nie zdołało się jeszcze przeobrazić w nowe formy [...], a w większości regjonów bibljotecznych, bibljoteki, mimo propagandy bib pochodowej $\left[{ }^{136}\right]$ nie cieszą się popularnością wśród mas robotniczych, słowem nie grają takiej roli jaką im nakazuje «budowa socjalistycznego państwa od podstaw» ${ }^{137}$.

131 M. Heller, Maszyna..., s. 216.

132 И.В. Новосадский, Теория книговедения и марксизм. Критика современного книговедения, „Труды Музея Книги, Документа и Письма” 1931, вып. 1, s. 3-46.

133 K. Migoń, Nauka o książce..., s. 60-63, 66; tenże, Z problematyki..., s. 7.

134 H. Radlińska, Ideały bibliotek powszechnych w Rosji, „Polska Oświata Pozaszkolna” 1924, z. 2, s. 76

135 W. Dobrowolska, Bibliotekarstwo w Rosji Sowieckiej..., s. 91.

136 Od «bibliotecznyj pochod» - nazwy akcji na rzecz szybkiego rozwoju bibliotekarstwa w ZSRR zainicjowanej w 1929 r., cyt. za W. Dobrowolska, Bibliotekarstwo w Rosji Sowieckiej..., s. 86,90 .

137 W. Dobrowolska, Rosja Sowiecka [Przegląd czasopism], „Przegląd Biblioteczny” 1932, R. 6, s. 63. 
- Wśród źródeł cytowanych przez A.W. Kwiatkowskiego brakuje ważnych aktów prawnych z lat 20-30. XX w. Należało do nich rozporządzenie z $1934 \mathrm{r}$. o bibliotekarstwie (О библиотечном деле в Союзе ССP) Centralnego Komitetu Wykonawczego ZSRR (Центральный исполнительный комитет Союза CCP) $)^{138}$, które: „ujednostajnia całą pracę państwową w dziedzinie bibliotekarstwa, centralizuje tę pracę, reguluje sprawę tworzenia nowych kadr bibliotekarskich, jak również dokształcania zawodowego bibliotekarzy już pracujących" "139. Pozostając przy problematyce bibliotekarskiej można też wskazać na pominięcie przez autora centralnego Urzędu Bibliotecznego (Библиотечное управление Наркомпроса РСФСР ${ }^{140}$ ).

- Mimo wszystkich niedoskonałości, w tym braków, pomyłek, np. w nazwiskach cytowanych autorów, pewnej chaotyczności narracji A.W. Kwiatkowskiego można zaryzykować tezę, że jego „Teorja psychosfery z jej metodą bibljologiczną" stanowi najpełniejszy, syntetyczny opis kultury książki sowieckiej w latach 20-30. XX w. w porównaniu do przedwojennych polskich publikacji zajmujących się tą problematyką ${ }^{141}$.

\section{Bibliografia}

Źródła archiwalne:

Archiwum Akt Nowych w Warszawie, zespół 102/I-III, Instytut Naukowego Badania Komunizmu w Warszawie (Księgozbiór A. Kwiatkowskiego). Opracowania referatowe, korespondencja, odezwy.

Hoover Institution Archives, Stanford University, 94305-6010, California, Collection number: 71013, Antoni Wincenty Kwiatkowski Papers:

- [Box no. 1], A.W. Kwiatkowski, Biografia nie podlegająca publikowaniu. Życiorys Księdza Antoniego-Wincentego Kwiatkowskiego = Typewritten biography of A. Kwiatkowski [ukończony 1 maja 1955 r.]; The Auto-Biography of Priest Antoni Vincenti Kwiatkowski.

138 О библиотечном деле в Союзе ССP, [online] https://www.lawmix.ru/docs_cccp/3804 [dostęp 27.08.2018].

139 I. Berezowska-Morsztynkiewiczowa, Z.S.R.R. Krasnyj bibliotekar, „Bibliotekarz” 19341936, R. 6, nr 12, s. 126.

140 Na ten temat zob. m.in. М.Н. Глазков, Репрессированные советские библиотечно-библиографические деятели 1930-1941 г2. Учебное пособие, Москва 2014.

141 Oprócz pozycji wymienionych w przypisach por. m.in. M. Rulikowski, Księgoznawstwo. Przeszłość oraz stan obecny wiedzy o książe i nowe $w$ niej kierunki, Warszawa 1935, s. 70-74; W.J. Živny, Bibliografia i bibliologia. Pojęcie, przedmiot, rozwój, tłum. A. Łysakowski, Warszawa-Wilno 1936, s. 77-79. Piśmiennictwo sowieckie poświęcone poszczególnym kwestiom składającym się na kulturę książki w ZSRR najczęściej omawiano na łamach „Przeglądu Bibliotecznego” i ,Bibliotekarza”. 
- [Box no. 6], Several typewritten manuscripts by A. Starodworski, with annotations by A. Kwiatkowski, A. Starodworski, Struktura i tajemnice centralnej organizacji bolszewizmu markso-leninowskiego, t. 2.

Publikacje:

A.S., Trudy Instituta Knigi, Dokumenta i Pisma. II. Stat i po historii enciklopedij. Leningrad 1932. Izd-wo Akad. Nauk. SSR. $8^{\circ}$, str 4 nlb. + 72, „Przegląd Biblioteczny” 1933, R. 7, s. 175-179.

Андреева О.В., История книжного дела в документальных источниках и материалах периодической печати, [online] http://www.hi-edu.ru/e-books/xbook984/01/part-003.htm [dostęp 15.08.2018].

Berezowska-Morsztynkiewiczowa I., Z.S.R.R. Krasnyj bibliotekar, „Bibliotekarz” 1934 1936, R. 6, nr 12, s. 126-127.

Berezowska-Morsztynkiewiczowa I., Z.S.R.R. Krasnyj bibliotekar, „Bibliotekarz” 19371938, nr 2, s. 39-40.

Bieńkowski W., O pseudo-nauce bibliologii i o najpilniejszych zadaniach bibliografii, Warszawa 1953.

Bocheński A., Stużba bibliograficzna w ZSRR, „Przegląd Biblioteczny” 1953, z. 1, s. 25-40. Большая советская энииклопедия, Москва 1926-1947.

Бумажная промышленность, [online] https://dic.academic.ru/dic.nsf/ bse/71691/\%D0\%91\%D1\%83\%D0\%BC\%D0\%B 0\%D0\%B6\%D0\%BD\%D0\%B0\%D1\%8F [dostęp 12.03.2018].

Хлебцевич Е.И., Изучение читательских интересов иироких масс (из опыта библиотечной работы в Красной Армии), Москва 1923.

Чувиков П.А., «Летописи» Всесоюзной книжной палаты, органы государственной библиографии, периодчческие указатели, профилированные по видам изданий, выпускаемых в СССР, [online] https://www.booksite.ru/fulltext/1/001/008/069/941. htm [dostęp 15.08.2018].

Dobrowolska W., Bibliotekarstwo w Rosji Sowieckiej. Krasnyj Bibliotekar - Żurnat Bibliotecznoj Teorii i Praktiki. - Organ Gławpolitprosweta. Pod redakciej M. A. Smuszkowoj. Gosudarstwennoje izdatelstwo [Moskwa] 1929. God izdanija sedmoj, „Przegląd Biblioteczny" 1931, R. 5, s. 85-92.

Dobrowolska W., Ideologia bibliotekarstwa w Rosji Sowieckiej, Kraków 1934.

Dobrowolska W., Rosja Sowiecka [Przegląd czasopism], „Przegląd Biblioteczny” 1932, R. 6, s. 61-66.

Фогелевич Л.Г., Основные директивы и законодательство о печати, издание пятое, Москва 1935.

Фридьева Н., Балика Д., Изучение читателя (опыт методики), под ред. М.А. Смушковой, Москва-Ленинград 1927.

Глазков М.Н., Репрессированные советские библиотечно-библиографические деятели 1930-1941 гг. Учебное пособие, Москва 2014. 
Głombiowski K., Ksiażka w komunikacji społecznej, Wrocław 1980.

Głombiowski K., O funkcjonalną koncepcję nauki o książce, „Studia o Książce” 1970, t. 1, s. 5-24.

Goban-Klas T., Literacki Gułag. Gławlit, czyli najwyższe stadium cenzury, [w:] Piśmiennictwo - systemy kontroli - obiegi alternatywne. T. 1, pod red. J. Kosteckiego, A. Brodzkiej, Warszawa 1992, s. 46-59.

Heller M., Maszyna i śrubki. Jak hartował się człowiek sowiecki, Warszawa 1989.

Институт Книги, Документа и Письма, [online] http://redkayakniga.ru/knigovedenie/item/f00/s00/e0000776/index.shtml [dostęp 25.08.2018].

История книги. Учебник для вузов, под ред. А.А. Говорова, Т.Г. Куприяновой, Москва 1998, [online] http://www.hi-edu.ru/e-books/HB/21-1.htm [dostęp 12.03.2018].

Канторович Я.А., Авторское право, Москва 1926.

«Книга и Пролетарская Револючия», [online] https://iterary_encyclopedia.academic. $\mathrm{ru} / 6275 / \% \mathrm{C} 2 \% \mathrm{AB} \% \mathrm{D} 0 \% 9 \mathrm{~A} \% \mathrm{D} 0 \% 9 \mathrm{D} \% \mathrm{D} 0 \% 98 \% \mathrm{D} 0 \% 93 \% \mathrm{D} 0 \% 90 \_\% \mathrm{D} 0 \% 98 \_\%$ D0\%9F\%D0\%A0\%D0\%9E\%D0\%9B\%D0\%95\%D0\%A2\%D0\%90\%D0\%A0\%D0 \%A1 [dostęp 16.08.2018].

Книговедение. Энииклопедический словарь, гл. ред. Н.М. Сикорский, Москва 1981.

Kondek S.A., Papierowa rewolucja. Oficjalny obieg książek w Polsce w latach 19481955, Warszawa 1999.

Kwiatkowski A.W., Na froncie intelektualnej ofensywy Bolszewizmu, Warszawa 1932.

Малая советская энциклопедия, Москва 1928-1931.

Marszał M., Komunizm w poglądach Antoniego Kwiatkowskiego (1920-1939), „Studia nad Autorytaryzmem i Totalitaryzmem" 2014, nr 2, s. 87-100.

Memoriat - ulotka na temat Instytutu Komunologicznego opublikowana przez A.W. Kwiatkowskiego w Warszawie prawdopodobnie w $1927 \mathrm{r}$.

Мезьер А.В., Словарный указатель по книговедению. Т. 2-4, Москва-Ленинград 1931-1934.

Migoń K., Bibliografia pod presją ideologii. Augusta Mézieres i jej «Stowarnyj ukazatiel po knigowiedieniju», [w:] W kręgu ksiażki, biblioteki i informacji naukowej. Księga jubileuszowa dedykowana Profesorowi Zbigniewowi Żmigrodzkiemu, pod red. K. Heskiej-Kwaśniewicz, przy współpracy D. Pietruch-Reizes, Katowice 2004, s. 193-207.

Migoń K., «Kultura książki»-wyrażenie potoczne, kategoria badawcza, czy specjalność naukowa?, [w:] Ludzie i książki. Studia i szkice bibliologiczno-bibliograficzne. Księga pamiątkowa dedykowana Profesor Hannie Tadeusiewicz, [red. W. Andrysiak], Łódź 2011, s. 47-57.

Migoń K., Nauka o książce. Zarys problematyki, Wrocław 1984.

Migoń K., Z dziejów nauki o książce, Wrocław 1979.

Migoń K., Z problematyki teorii księgoznawstwa w ZSRR, „Acta Universitatis Wratislaviensis” nr 72 „Bibliotekoznawstwo” 1968, t. 5, s. 3-30.

Narodziny kołchozów, „Światowid” 03.09.1933, R. 10, nr 36 (473). 
Новосадский И.В., Теория книговедения и марксизм. Критика современного книговедения, „Труды Музея Книги, Документа И Письма” 1931, вып.1, s. 3-46.

О библиотечном деле в Союзе ССР, [online] https://www.lawmix.ru/docs_cccp/3804 [dostęp 27.08.2018].

Об утверждении устава Государственного объединения книжно-журнальных издательств РСФСР (ОГИЗ), Положения о Центре книго-журнального распространения (Книгочентр) и типового положения о государственном издательстве, входящем в Объединение ,ОГИЗ”. Постановление СНК РСФСР om 08.10.1930, [online] http://7law.info/ussr/act8u/r988.htm [dostęp 12.03.2018].

Постановление СНК РСФСР об утверждении положения о Главном управлении по контолю за зрелищами и репертуаром при Наркомпросе РСФСР, 26 февраля 1934, [online] http://www.opentextnn.ru/censorship/russia/sov/law/sn$\mathrm{k} / 1931 /$ ?d=1216 [dostęp 23.07.2018].

Пропагандист, [online] https://dic.academic.ru/dic.nsf $/$ bse/124334/\%D0\% $9 \mathrm{~F} \% \mathrm{D} 1 \% 80 \% \mathrm{D} 0 \% \mathrm{BE} \% \mathrm{D} 0 \% \mathrm{BF} \% \mathrm{D} 0 \% \mathrm{~B} 0 \% \mathrm{D} 0 \% \mathrm{~B} 3 \% \mathrm{D} 0 \% \mathrm{~B} 0 \% \mathrm{D} 0 \% \mathrm{~B}-$ D\%D0\%B4\%D0\%B8\%D1\%81\%D1\%82 [dostęp 16.08.2018].

„Полиграфия”, [online] http://redkayakniga.ru/knigovedenie/item/f00/s01/e0001592/ index.shtml [dostęp 12.03.2018].

Puchalski J., Bibliologia w ZSRS w okresie międzywojennym w interpretacji księdza Antoniego Wincentego Kwiatkowskiego (1890-1970), [w:] Szlachta polska i jej dziedzictwo. Księga na 65 lat prof. dr hab. Jana Dzieggielewskiego, [red. D. Kuźmina], Warszawa 2013, s. 259-273.

Puchalski J., Instytut Naukowego Badania Komunizmu w Warszawie (1930-1939). Program, organizacja, zbiory prace księgoznawcze, [w:] Bibliologia polityczna. Praca zbiorowa, pod red. D. Kuźminy, Warszawa 2011, s. 214-243.

Путеводители по Архивам России. Фонды центральных органов государственного управления СССР и подведомственных им учреждений. Учебные заведения, [online] http://guides.rusarchives.ru/browse/guidebook.html?bid=203\&sid=1152247 [dostęp 12.03.2018].

Radlińska H., Ideały bibliotek powszechnych w Rosji, „Polska Oświata Pozaszkolna” 1924, z. 2, s. 75-88.

Росси́йская Ассоциа́ции Пролета́рских Писа́телей, [online] https://bigenc.ru/literature/text/3515393 [dostęp 11.03.2018].

Рубакин Н.А., Что такое библиологическая психология?, Ленинград 1924.

Рубакин Н.А., Психология читателя и книги. Краткое введение в библиологическую психологию, Москва 1929.

Rulikowski M., Księgoznawstwo. Przeszłość oraz stan obecny wiedzy o ksiązce i nowe w niej kierunki, Warszawa 1935.

Sacewicz K., Komunizm i antykomunizm w II Rzeczypospolitej. Państwo-społeczeństwo-partie, Olsztyn 2016. 
Сомов Н.М., Состав книговедения: библиология - библиография - журнализм. К построению системы книговедения, Москва 1931.

Starodworski A., Katolicyzm a komunizm, Warszawa 1936.

Starodworski A., Psychosfera w Z.S.S.R., „Nasza Przyszłość” 1931, t. 13, s. 95-128.

Статьи и материаль по истории книги в России, Москва-Ленинград 1936. Труды Института книги, документа и письма, вып. 5.

Столяров Ю.Н., Столетие библиотечного образования в СНГ и республиках ближнего зарубежья, [online] http://docplayer.ru/216495-Stoletie-bibliotechnogo-obrazovaniya-v-sng-i-respublikah-blizhnego-zarubezhya.html [dostęp 24.08.2018].

Шафрановский К.И., Работа Книжной палаты в Петрограде, [online] https://100bookchamber.blogspot.com/2016/11/K-I-Shafranovskij-Rabota-Knizhnoj-Palaty-v-Petrograde.html [dostęp 15.08.2018].

Таль Б.М., О задачах большевистской печати, Москва 1936.

Vrtel-Wierczyński S., Teoria bibliografii w zarysie, Wrocław 1951.

Živny W.J., Bibliografia i bibliologia. Pojęcie, przedmiot, rozwój, tłum. A. Łysakowski, Warszawa-Wilno 1936. 